NASA/CR—2007-215020

(2x)

A Database of Supercooled Large Droplet Ice Accretions

Judith Foss Van Zante

ASRC Aerospace Corporation, Cleveland, Ohio 


\section{NASA STI Program . . . in Profile}

Since its founding, NASA has been dedicated to the advancement of aeronautics and space science. The NASA Scientific and Technical Information (STI) program plays a key part in helping NASA maintain this important role.

The NASA STI Program operates under the auspices of the Agency Chief Information Officer. It collects, organizes, provides for archiving, and disseminates NASA's STI. The NASA STI program provides access to the NASA Aeronautics and Space Database and its public interface, the NASA Technical Reports Server, thus providing one of the largest collections of aeronautical and space science STI in the world. Results are published in both non-NASA channels and by NASA in the NASA STI Report Series, which includes the following report types:

- TECHNICAL PUBLICATION. Reports of completed research or a major significant phase of research that present the results of NASA programs and include extensive data or theoretical analysis. Includes compilations of significant scientific and technical data and information deemed to be of continuing reference value. NASA counterpart of peer-reviewed formal professional papers but has less stringent limitations on manuscript length and extent of graphic presentations.

- TECHNICAL MEMORANDUM. Scientific and technical findings that are preliminary or of specialized interest, e.g., quick release reports, working papers, and bibliographies that contain minimal annotation. Does not contain extensive analysis.

- CONTRACTOR REPORT. Scientific and technical findings by NASA-sponsored contractors and grantees.
- CONFERENCE PUBLICATION. Collected papers from scientific and technical conferences, symposia, seminars, or other meetings sponsored or cosponsored by NASA.

- SPECIAL PUBLICATION. Scientific, technical, or historical information from NASA programs, projects, and missions, often concerned with subjects having substantial public interest.

- TECHNICAL TRANSLATION. Englishlanguage translations of foreign scientific and technical material pertinent to NASA's mission.

Specialized services also include creating custom thesauri, building customized databases, organizing and publishing research results.

For more information about the NASA STI program, see the following:

- Access the NASA STI program home page at http://www.sti.nasa.gov

- E-mail your question via the Internet to help@sti.nasa.gov

- Fax your question to the NASA STI Help Desk at 301-621-0134

- Telephone the NASA STI Help Desk at 301-621-0390

- Write to: NASA Center for AeroSpace Information (CASI) 7115 Standard Drive Hanover, MD 21076-1320 
NASA/CR-2007-215020

SAE 2007-01-3348

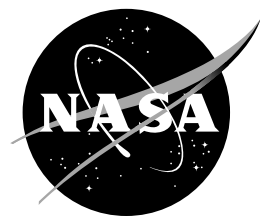

\section{A Database of Supercooled Large Droplet Ice Accretions}

Judith Foss Van Zante

ASRC Aerospace Corporation, Cleveland, Ohio

Prepared for the

Aircraft and Engine Icing International Conference

sponsored by the SAE International

Seville, Spain, September 24-27, 2007

Prepared under Contract NNC06BA07B

National Aeronautics and

Space Administration

Glenn Research Center

Cleveland, Ohio 44135 


\section{Acknowledgments}

The author would like to thank Dr. Mark Potapczuk and Dean Miller for their invaluable input and support of this undertaking, the IRT Crew for their superior efforts, Tammy Langhals for digitizing all the ice shape tracings as well as running THICK, and intern Matt Ferraro for programming the companion SLD Icing Database DVD.

This report is a preprint of a paper intended for presentation at a conference.

Because changes may be made before formal publication, this preprint is made available

with the understanding that it will not be cited or reproduced without

the permission of the author.

Trade names and trademarks are used in this report for identification only. Their usage does not constitute an official endorsement, either expressed or implied, by the National Aeronautics and Space Administration.

Level of Review: This material has been technically reviewed by a NASA reviewer.

Available from

NASA Center for Aerospace Information 7115 Standard Drive

Hanover, MD 21076-1320
National Technical Information Service 5285 Port Royal Road Springfield, VA 22161 


\title{
A Database of Supercooled Large Droplet Ice Accretions
}

\author{
Judith Foss Van Zante \\ ASRC Aerospace Corporation \\ Cleveland, Ohio 44135
}

\begin{abstract}
A unique, publicly available database regarding supercooled large droplet ice accretions has been developed in NASA Glenn's Icing Research Tunnel. Identical cloud and flight conditions were generated for five different airfoil models. The models chosen represent a variety of aircraft types from the horizontal stabilizer of a large transport aircraft to the wings of regional, business, and general aviation aircraft. In addition to the standard documentation methods of 2D ice shape tracing and imagery, ice mass measurements were also taken. This database will also be used to validate and verify the extension of the ice accretion code, LEWICE, into the SLD realm.
\end{abstract}

\section{Introduction}

The crash of an ATR-72 in Roselawn, Indiana on 31 October 1994 due to supercooled large droplet (SLD) icing focused attention on the need to better understand this condition. Still on the National Transportation Safety Board's (NTSB) \#1 Most Wanted Transportation Safety Improvement in Aviation (ref. 1) is to

Reduce Dangers to Aircraft Flying in Icing Conditions

Specifically to

Use current research on freezing rain and large water droplets to revise the way aircraft are designed and approved for flight in icing conditions.

Conduct additional research with NASA to identify realistic ice accumulations and incorporate new information into aircraft certification and pilot training requirements. [Italics added]

This work addresses part of NASA's effort to identify these realistic ice accumulations. Based on this, NASA and its partners developed an SLD Technology Roadmap (ref. 2). This map identified the need to provide a database of realistic SLD ice shapes, and to modify accretion codes to accurately model SLD conditions. The database work has been done in conjunction with SLD Sensitivity (ref. 3) and Methods studies, also conducted in the Icing Research Tunnel (IRT).

\section{Methodology}

\section{Models}

Five different models from the IRT livery were tested. An essential requirement for selection was that the model be full span (72 in.) with a minimum chord of 36 in. Four of the five models were 2D. The fifth model, a Business Jet Wing, had slight sweep $\left(9^{\circ}\right)$, taper (from 66.8 to 55.3 in. over the 72 in. span) and twist. The model also had a thermal ice protection system to 8 percent chord. These models are described in table 1 and figure 1, and pictured as installed in the IRT in appendix A. Note, Entry A occurred in December 2004. The results from this test provided the impetus to improve the SLD cloud uniformity in the tunnel. Entries B to F occurred after IRT facility modification substantially improved the cloud uniformity.

Table 1. SLD database test identifier, model, centerline (CL) chord, characteristics and start dates.

\begin{tabular}{|c|l|c|l|c|}
\hline $\begin{array}{c}\text { Test } \\
\text { Entry }\end{array}$ & \multicolumn{1}{|c|}{ Model } & $\begin{array}{c}\text { CL } \\
\text { Chord } \\
\text { (in.) }\end{array}$ & $\begin{array}{c}\text { Model } \\
\text { characteristics }\end{array}$ & $\begin{array}{c}\text { Test start } \\
\text { date }\end{array}$ \\
\hline B & NLF 0414 & 36 & $\begin{array}{l}\text { 2D, Fiberglass } \\
\text { and wood }\end{array}$ & $\begin{array}{c}\text { 16 February } \\
2006\end{array}$ \\
\hline C & $\begin{array}{l}\text { NACA } \\
23012\end{array}$ & 72 & $2 \mathrm{D}$, Aluminum & $\begin{array}{c}\text { 02 March } \\
2006\end{array}$ \\
\hline D & GLC 305 & 36 & 2D, Aluminum & $\begin{array}{c}28 \text { March } \\
2006\end{array}$ \\
\hline E & $\begin{array}{l}\text { Commercial } \\
\text { tail }\end{array}$ & 36 & 2D, Fiberglass & $\begin{array}{c}22 \text { May } \\
2006\end{array}$ \\
\hline F & $\begin{array}{l}\text { Business jet } \\
\text { wing }\end{array}$ & 61 & 3D, Aluminum, \\
Thermal LE & $\begin{array}{c}\text { 17 January } \\
2007\end{array}$ \\
\hline
\end{tabular}

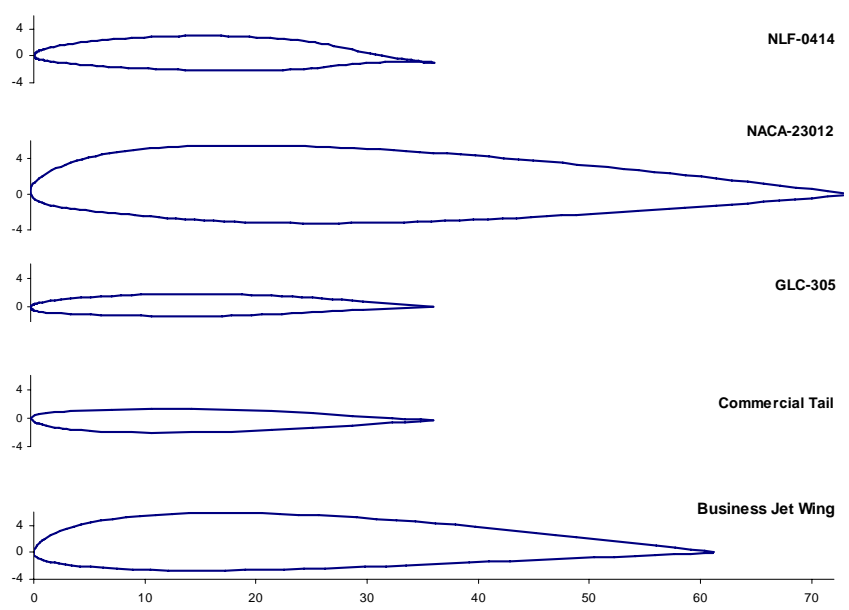

Figure 1. Model cross-sections in physical coordinates. 
Models with imbedded pressure taps were aligned aerodynamically via comparison with existing experimental or theoretical CP curves (Entries B, C, and E). For Entry D, the IRT's force balance and wake survey systems were also installed. The model was aligned by finding the angle with minimum drag. The force and wake survey data are not included here. For Entry F, the model was aligned by comparing an ice shape (specifically, the suction horn location) to a previous tracing. Thermocouples on every model were used to ensure that the model was cold-soaked prior to spray.

\section{Data Acquisition}

For each accretion, generally three types of data were recorded. Besides the standard documentation methods of ice shape tracing and photography, the mass from a spanwise section was also captured and weighed (figs. 2 and 3). Of primary interest was the "main" leading edge ice shape, whether this included the suction and pressure horns or runback-type shapes. The aft feather region experienced random shedding.

\section{Tracing}

The ice shape tracing data, taken at centerline, and sometimes other locations, yielded horn heights and angles for both suction and pressure sides of the "main" ice shape, and leading edge minimum height (fig. 2(a)).

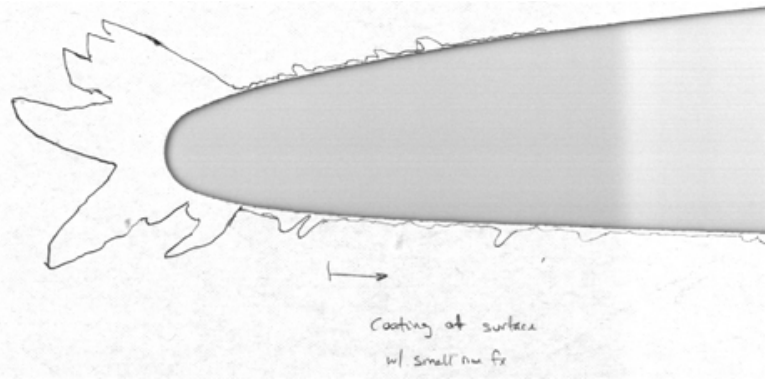

(a)

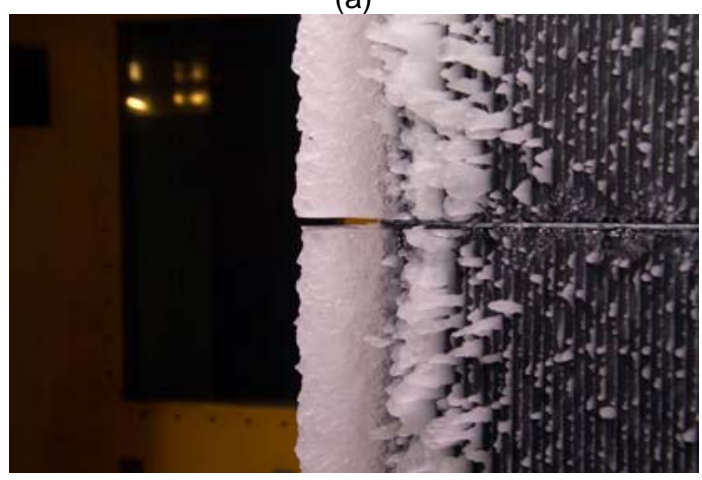

(b)

Figure 2. (a) Ice shape tracing sample, (b) and corresponding close-up of pressure surface. Heater placement and gap are also visible.

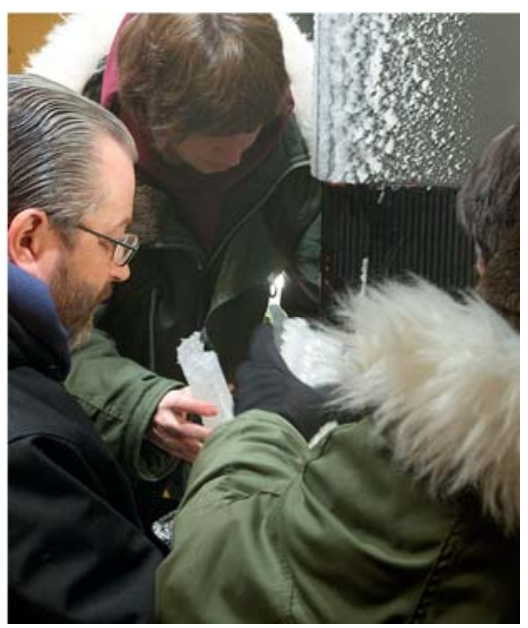

(a)

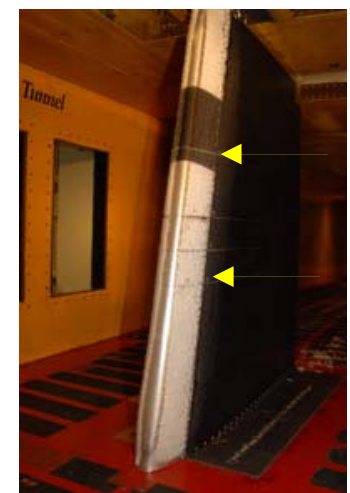

(b)
Figure 3. Ice collection process for mass measurement, (a) Procedures for Entries B to E; (b) for Entry F, ice was collected between top and bottom indicators.

These measures are used to compare to the computationally generated SLD ice shapes. The aft region of individual feathers was not always recorded and/or digitized in detail. Such a record was found to be problematic due to feather shedding and the artificial alignment of the feathers on the small ridges from the Minco heaters. To better understand the influence of these ridges, one day of testing (nominally 8 sprays) was conducted without the heaters for Entries $\mathrm{C}$ to $\mathrm{E}$.

To obtain the tracing, an ice knife (1/8 in.-thick copper sheet) was heated to cut the ice to the airfoil surface (fig. 2(b)). A cardboard template that had been cut to the model coordinates was then inserted into this slot so that it was snug with the model. The researcher traced the ice shape according to Icing Branch established guidelines (ref. 4). Note the traced shape is always a pencil radius thicker than the actual ice. A horizontal table, adjusted to the model centerline, helped facilitate the ice cutting and tracing process.

\section{Imagery}

After the cut and tracing, at least five views were captured with a digital camera: close-ups of the pressure side, leading edge and suction side, as well as longshots showing the entire span from both sides. A sampling of these types of images can be seen in appendix B.

\section{Ice Mass}

Ice mass measurements are a relatively recent option in the data collection process at the IRT. The ice mass, along with the area obtained from the 2D tracing (extruded over the collection span) can offer some 
insight about an average ice density. For this article, only the mass measurements are reported. Without a valid area recorded and/or digitized in the feather region, no such density calculations were attempted.

To obtain the mass measurements, four 10 by 15 in. (or 9 by 11 in. for Entry D) Thermofoil (Minco, Minneapolis) heater elements were wrapped to capture the impingement limits (worst case) from the suction to pressure sides. Heaters were wrapped on either side of the centerline, with a $5 \mathrm{~mm}$ gap to accommodate the ice knife and template. There was no apparent effect on the ice shape due to this gap. After all other data were captured, the heaters were turned on just enough to debond the ice from the surface. The main ice shape and feathers were scraped or placed into a pan (fig. 3(a)). For each run, the pan was weighed with and without the ice on a scale with accuracy $\pm 0.5 \mathrm{~g}$. The difference was the ice mass.

For the Business Jet wing, the internal thermal ice protection system was used in lieu of the heaters. Mass from the equivalent spanwise range, 20 in., was captured using two pans - one to catch the ice, the other as a dam to prevent the ice above from falling into the lower, measurement pan. As only the leading 8 percent of chord was heated, only the tops of the ice feathers aft of this region could be scraped into the pan - a thin layer of ice remained at the surface. This remaining mass is estimated to be less than 5 percent of the total.

\section{Test Conditions}

In the IRT, the researcher selects airspeed, model angle of attack, temperature, spray time, liquid water content (LWC) and median volume diameter (MVD) of the droplets. To reduce the SLD Database test matrix to a manageable size, several parameters were fixed. The spray time was set to $10 \mathrm{~min}$. The temperature was fixed at one of two values so that it was as warm as possible without risking a shed of the main ice shape. The angle of attack was also essentially fixed to a low, non-zero, value, chosen to match that model's testing history. The target for LWC and MVD was to map a roughly evenly spaced grid. That is for MVD, the researcher targeted MVD values in increments of $50 \mu \mathrm{m}: 50,100,150$ and 200 , and LWC values in increments of $0.25 \mathrm{~g} / \mathrm{m}^{3}: 0.25$, $0.50,0.75,1.00,1.25$, and 1.50 . The decision was also made to limit the matrix to IRT calibrated air speeds and spraybar pressures. The accuracies for the SLD cloud are subdivided into two droplet size ranges: for 40<MVD<100: LWC \pm 15 percent, MVD \pm 20 percent; for MVD>100: LWC $-10 /+30$ percent, MVD \pm 10 percent (ref. 5). The test matrix was constructed with three central objectives. The bulk of the data was built with a "basic matrix" that explored the IRT's range for LWC and MVD in the SLD regime. Also investigated was the capability of a "bimodal" spray condition. Finally, a hold or descent flight condition was represented.

\section{Basic Matrix}

The basic matrix is presented in table 2 . It included the four calibrated airspeeds: $V=100,150,200,250 \mathrm{kts}$, fixed $A O A$ at a low positive angle: $2^{\circ}$ for Entries $B$ to $E$ and $3^{\circ}$ or $-1^{\circ}$ for Entry $F$. The selected total temperatures were $T t=-5^{\circ} \mathrm{C}$ for 100 and $150 \mathrm{kts}$, or $-10^{\circ} \mathrm{C}$ for 200 and $2 \overline{50} \mathrm{kts}$. MVD and LWC values were limited to the SLD calibration points, and chosen to map as much of the IRT envelope as possible. In table 2, the grey-shaded boxes indicate points outside the IRT calibration. Due to the large range for the $100 \mathrm{kts}$ case, a further down-selection was required; the more extreme cases were explored.

Table 2. Basic test matrix. For each speed/temperature, the reference number and resulting MVD and LWC values are listed. Grey-shaded blocks lie outside of calibrated areas.

Reference number/MVD, LWC

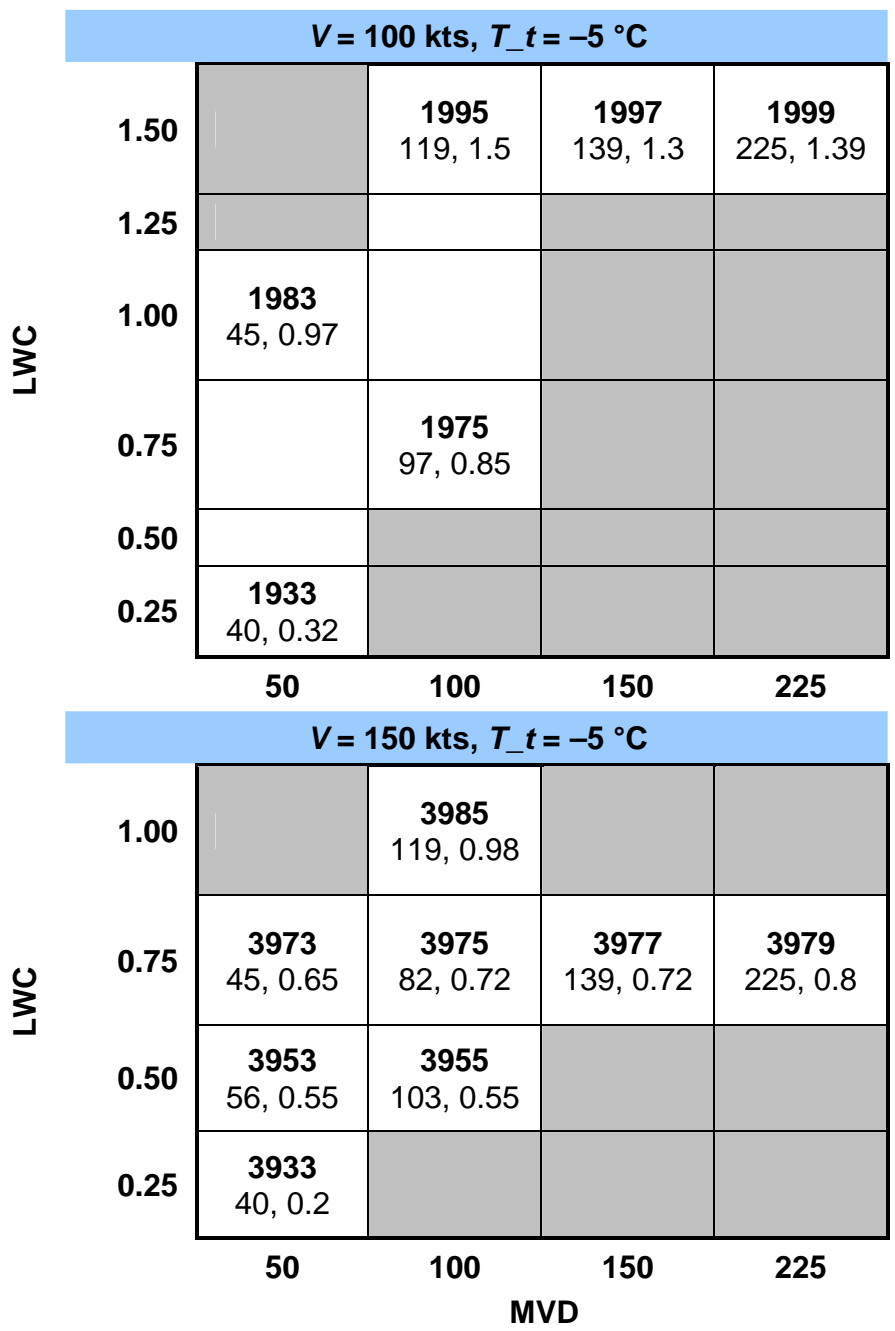



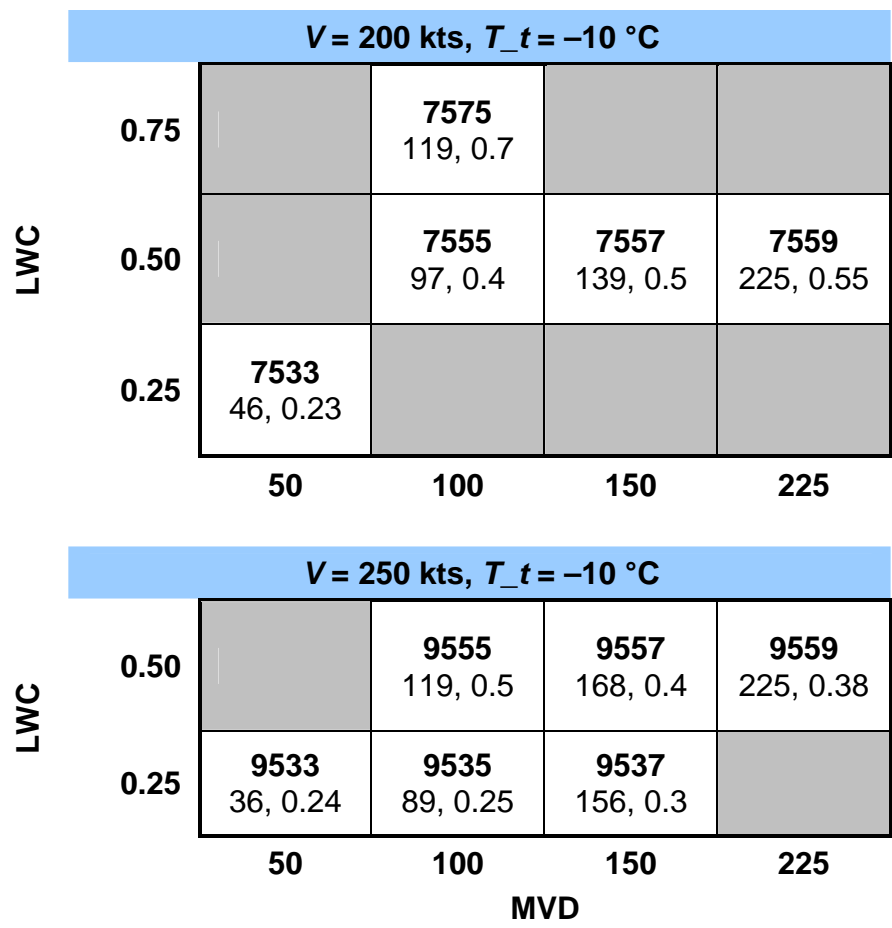

\section{Bimodal}

A condition that will be used in SLD certification is one that simultaneously contains both "small" and "large" droplets with an absence of droplet sizes in between. These are called bimodal conditions. In the IRT, this condition is simulated by spraying large then small droplets in an alternate manner. A key is to ensure that the freezing fraction for both clouds is the same. See Potapczuk and Miller (ref. 6) for further discussion.

For this study, a condition at $V=150 \mathrm{kts}$ and $T_{-} t=-5^{\circ} \mathrm{C}$, that met all the IRT constraints and matched a distribution proposed by the Meteorological Services of Canada (MSC2) is specified below and shown in figure 4.

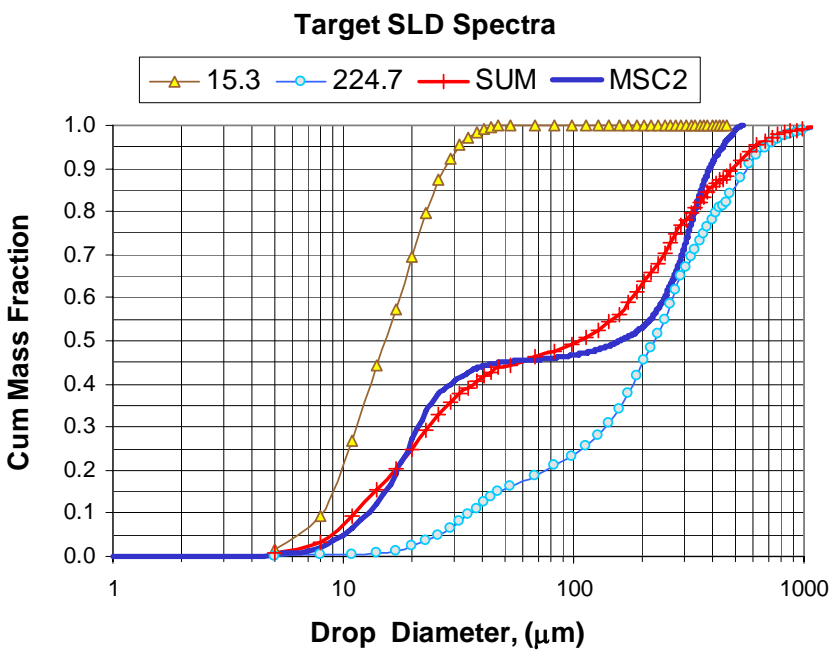

Figure 4. Target spectra for bimodal distribution (MSC).
Large: $\mathrm{LWC}=0.79 \mathrm{~g} / \mathrm{m}^{3}, \mathrm{MVD}=$ $225 \mu \mathrm{m}$ for 70 percent of the spray time, and Small: $\mathrm{LWC}=0.94 \mathrm{~g} / \mathrm{m}^{3}, \mathrm{MVD}=$ $15 \mu \mathrm{m}$ for the other 30 percent.

The 10-min bimodal spray (3979b) was achieved by alternating the large and small droplet conditions. The large droplet condition was sprayed three times for $2.33 \mathrm{~min}$. each, and the small droplet condition was sprayed twice at $1.5 \mathrm{~min}$. each. In addition, 10-min. sprays with only the small droplets (3979c) were run. Note the large droplet only spray was also run (3979). All bimodal conditions were run at the same model angle as the Basic Matrix.

\section{Flight Condition}

The flight condition was to simulate a relevant airspeed and AOA for a generic aircraft on which the wing section might be expected. ${ }^{*}$ When possible, this condition was repeated from an earlier database mostly from the Modern Airfoils (ref. 7) database. Specifically, for Entries B and C this hold AOA was $3^{\circ}$, a descent $A O A$ was $6^{\circ}$ for Entry $D$, and $-1^{\circ}$ for $E$.

On occasion, additional data on temperature or angle of attack effects were gathered.

\section{Data}

A more comprehensive report and a DVD with the full SLD Database are available in other references (refs. 8 and 9). For each model, the spray conditions, ice mass, 2D tracing, ice shape characteristics and images are given for every valid spray.

In this article, a small cross-section of the results is given here. Appendix B presents the 7575 spray condition for each of the five different models: $V=$ $200 \mathrm{kts}, t=10 \mathrm{~min} ., T_{-} t=-10^{\circ} \mathrm{C}, \mathrm{LWC}=0.7 \mathrm{~g} / \mathrm{m}^{3}$, MVD $=119 \mu \mathrm{m}$. This shape can be characterized by its welldefined "horns". Specifically presented are the digital images, the ice shape tracing from the centerline, and a table with the ice mass and ice shape characteristic data consisting of suction horn height and angle, pressure horn height and angle, leading edge minimum thickness. Also presented in appendix $\mathrm{B}$ is a runback-like case, 1999: $V=100 \mathrm{kts}, T_{-} t=-5{ }^{\circ} \mathrm{C}, \mathrm{LWC}=1.39$, MVC $=$ 225. The ice shape for this condition is presented with and without the heaters.

The ice shape characteristic data was obtained by running THICK (ref. 10) on the 2D ice shape coordinates. THICK is an additional output file from NASA's ice accretion code, LEWICE. Figure 5 illustrates how these measurements are calculated. Horn heights are measured

\footnotetext{
*There was no attempt to scale the cloud based on the model geometry.
} 


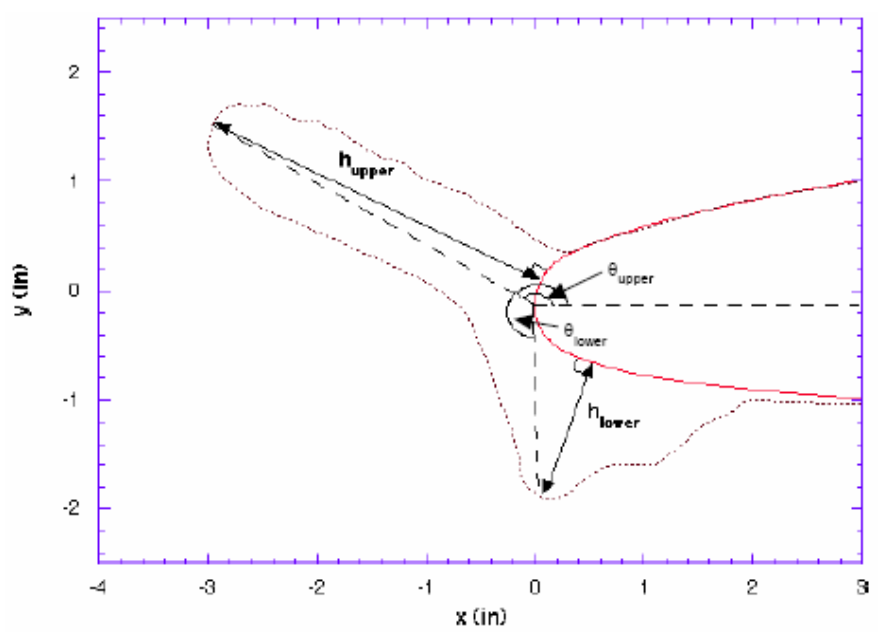

Figure 5. Sample ice shape illustrating the ice shape characteristics output by THICK.

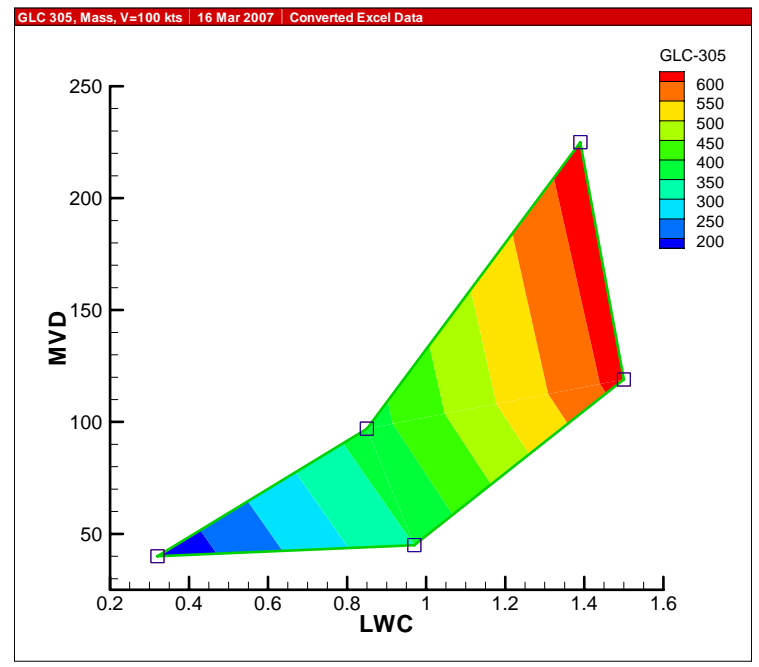

(a)

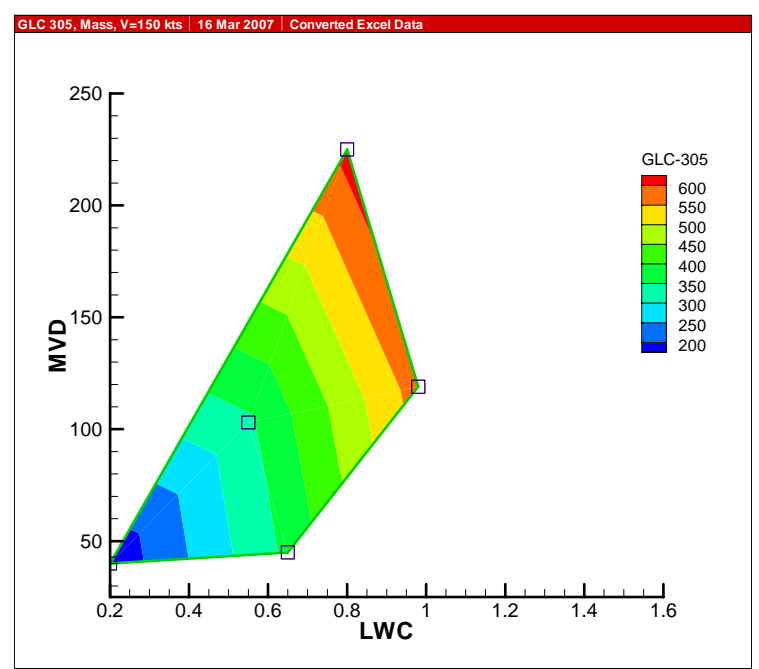

(c) from the surface normal to the peak height, whereas the horn angle is between the line straight aft of the leading edge and the line from the leading edge to the peak height. For this paper, the terms "pressure" and "suction" are used in lieu of "upper" and "lower" to reduce confusion when discussing the Commercial Tail. Also, note that the 2D tracing data are presented with the suction surface on top, regardless of how the model was installed in the tunnel.

Sample ice mass measurements are presented here graphically. For repeat conditions, the mass is averaged. Figure 6 presents the mass obtained for one model, the GLC 305, at each speed. The squares indicate the measured or averaged mass values, depending on whether the point was repeated or not. The contour colors are linearly interpolated within a graphing package (TecPlot, Bellevue).

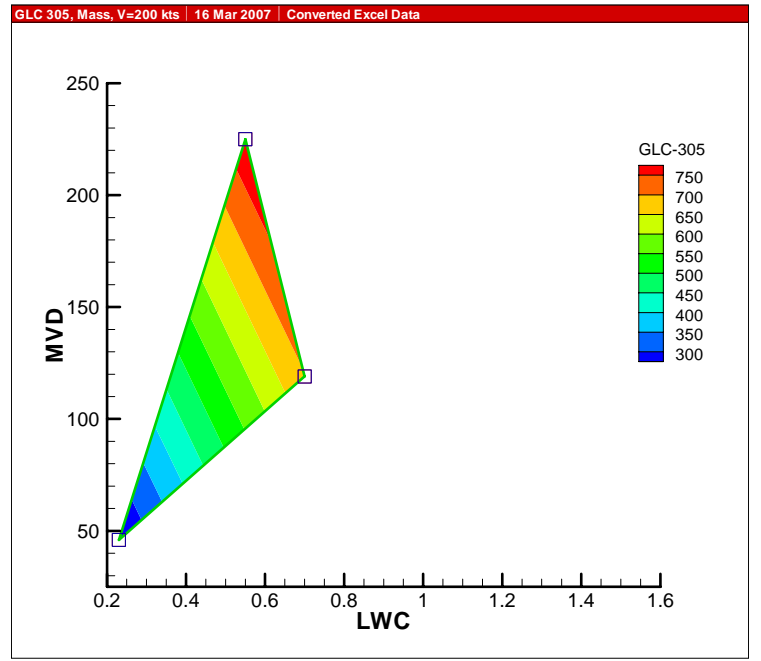

(b)

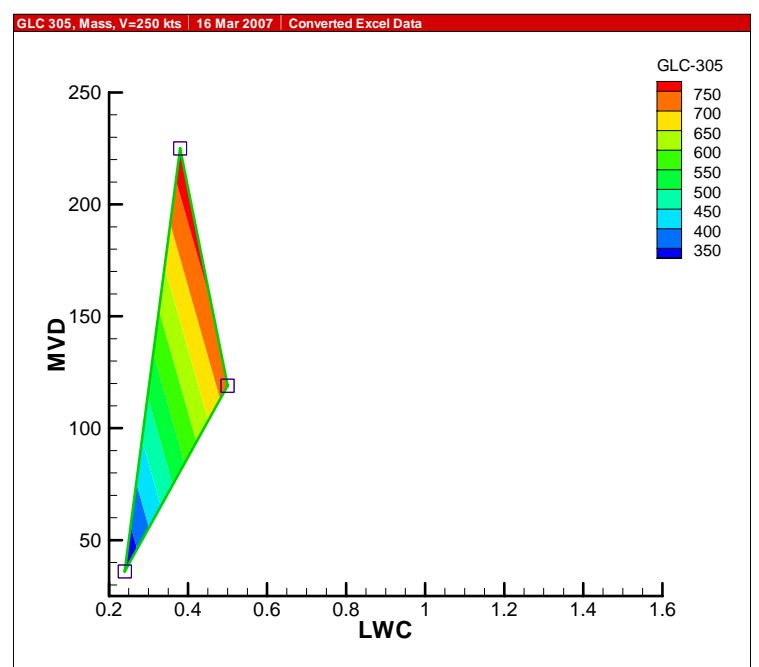

(d)

Figure 6. Mass (g) presented as a function of LWC and MVD for the GLC 305 model at V= (a) 100 kts, (b) 150 kts (c) $200 \mathrm{kts,}$ and (d) $250 \mathrm{kts}$. Note the different scales. 


\section{Conclusion}

A database of SLD ice shape accretions has been generated in NASA Glenn's Icing Research Tunnel. Five different full-span models experienced the same set of SLD spray conditions. A small sample of ice accretion images, 2D ice shape tracings and their characteristics, and ice mass data are presented here; a more complete data set is also available on a DVD included in the back of this document, and available from the NASA Center for Aerospace Information as NASA/CR-2007-215020/SUPPL. 


\section{Appendix A \\ Models}

Appendix A presents the five models as they were installed in the IRT. The pressure and suction sides are noted.
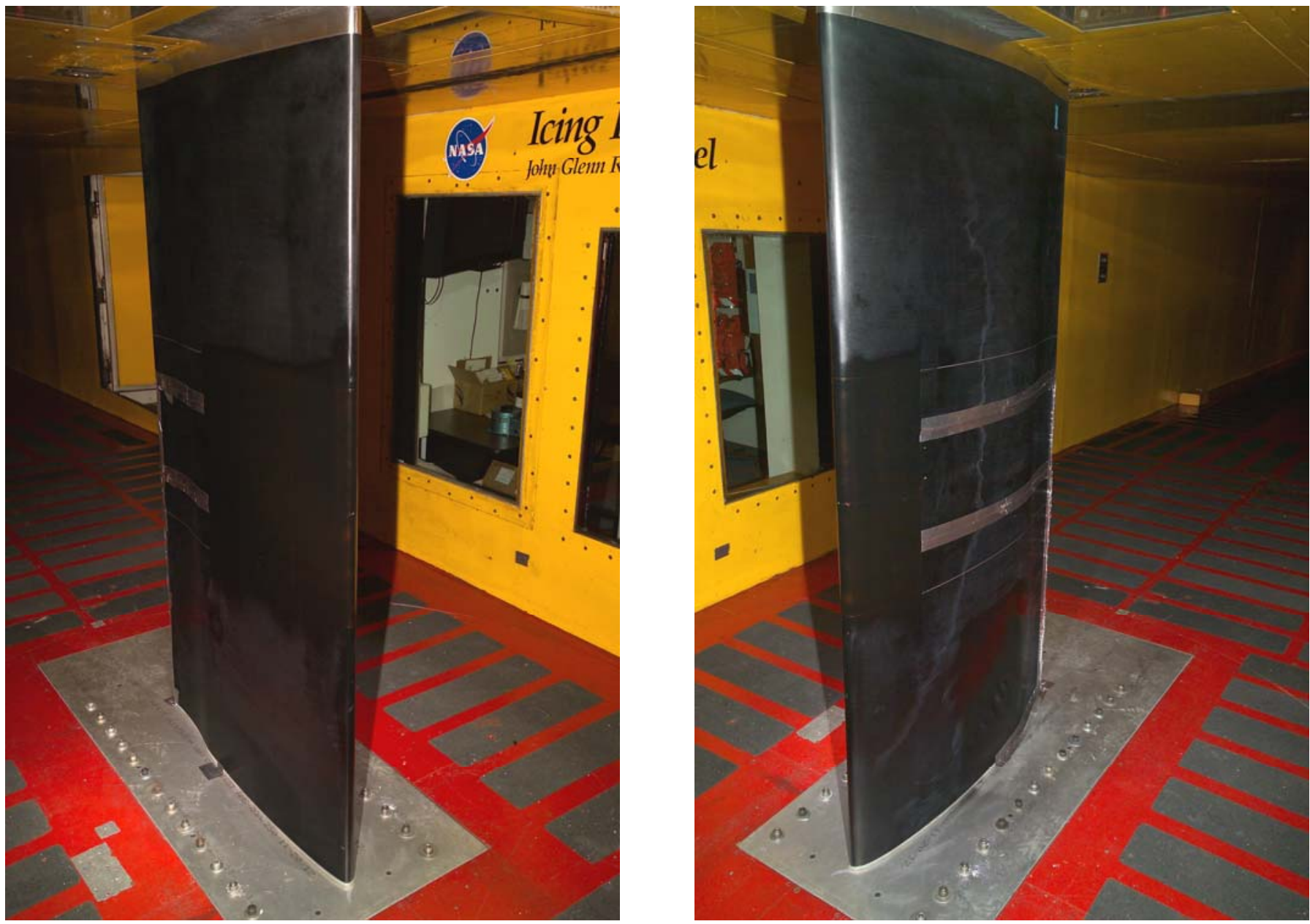

Figure A1. Entry B NLF 0414 airfoil in IRT ( $a$ = left) Pressure Side, $(b=$ right) Suction Side. 

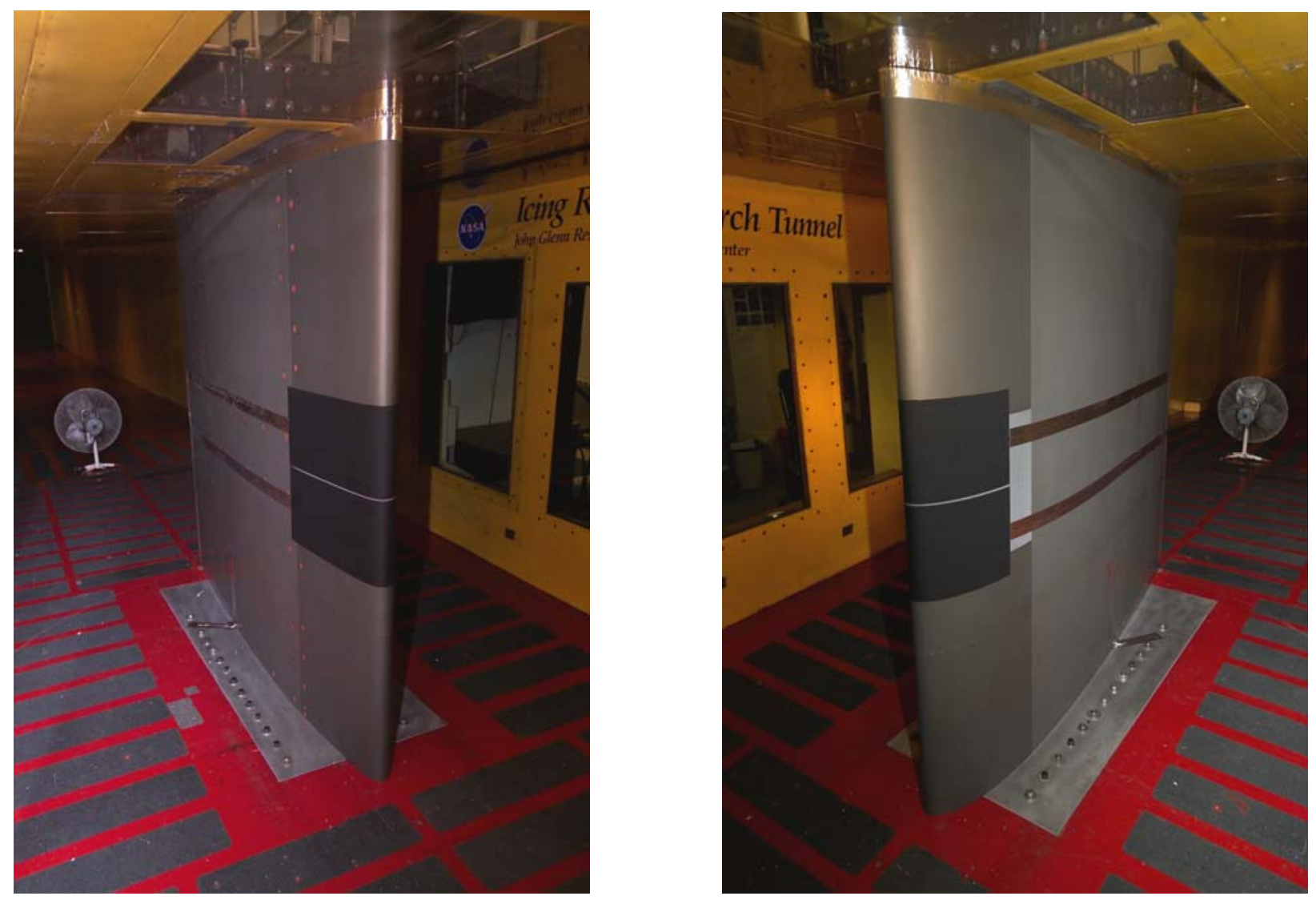

Figure A2. Entry C: NACA 23012 airfoil in IRT ( $a=$ left) Pressure Side, ( $b=$ right) Suction Side.
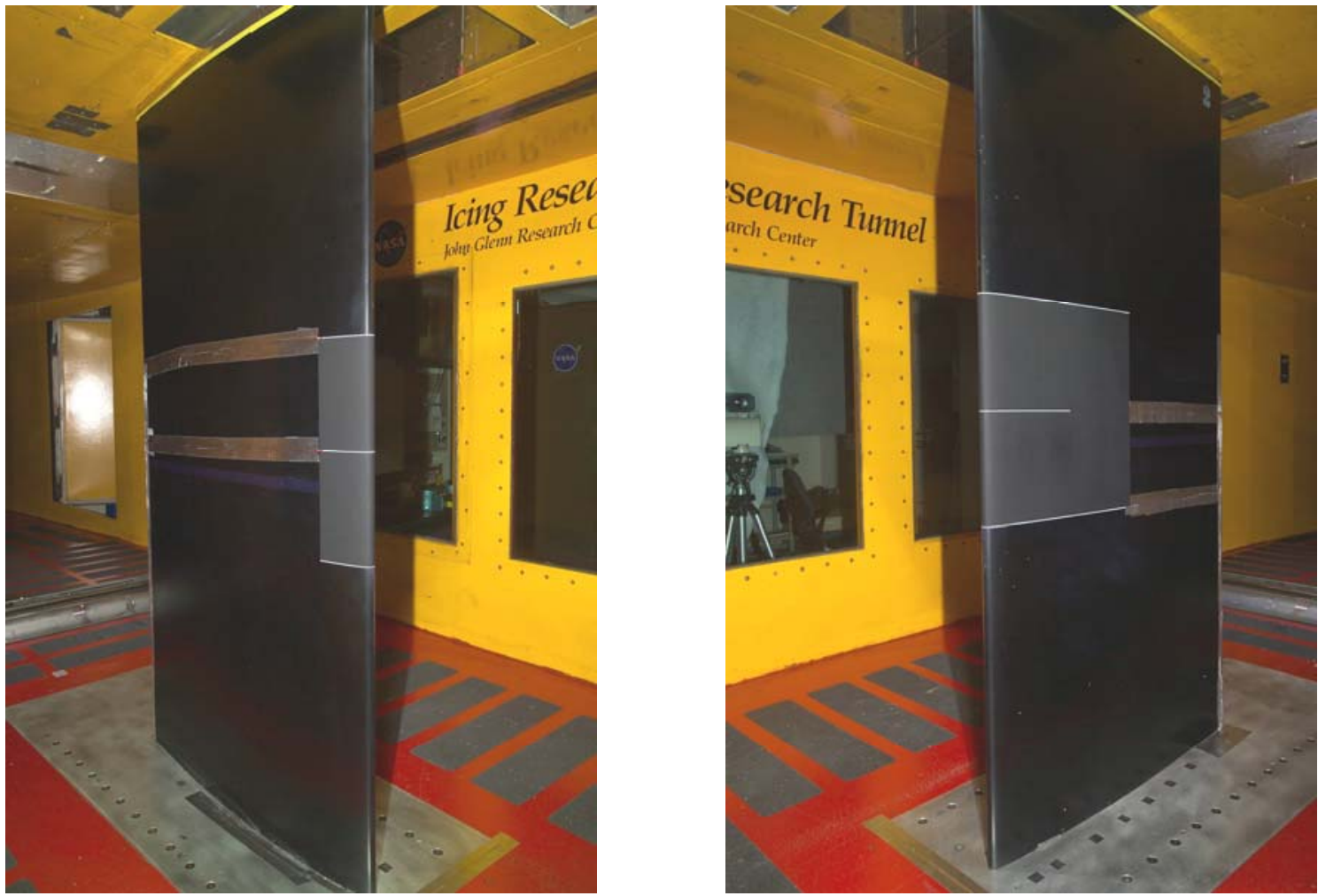

Figure A3. Entry D (and A) GLC 305 (a = left) Suction Side, ( $b=$ right) Pressure Side. 

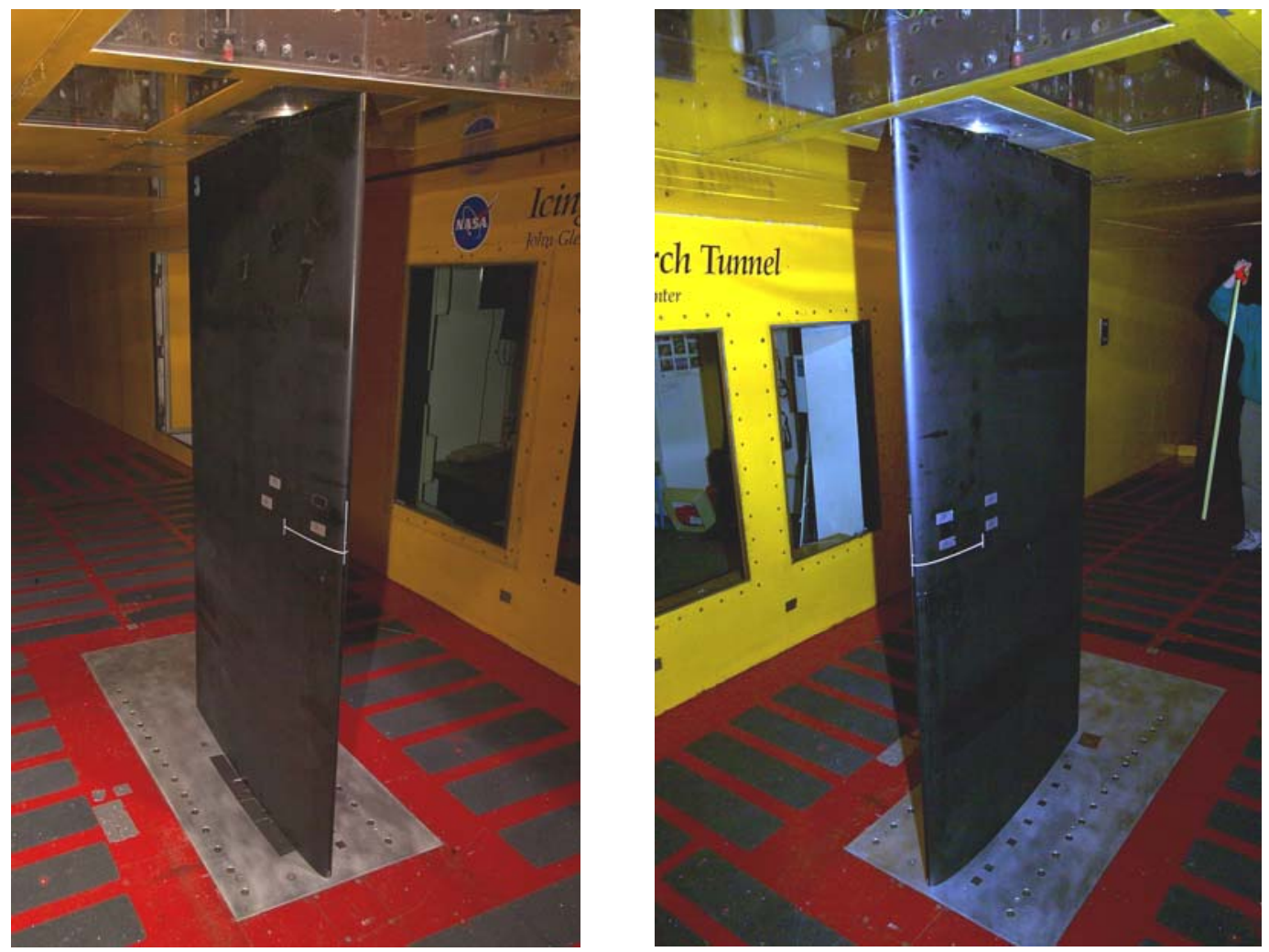

Figure A4. Entry E Commercial Tail airfoil in IRT $(a=$ left $)$ Pressure Side, $(b=$ right $)$ Suction Side. 

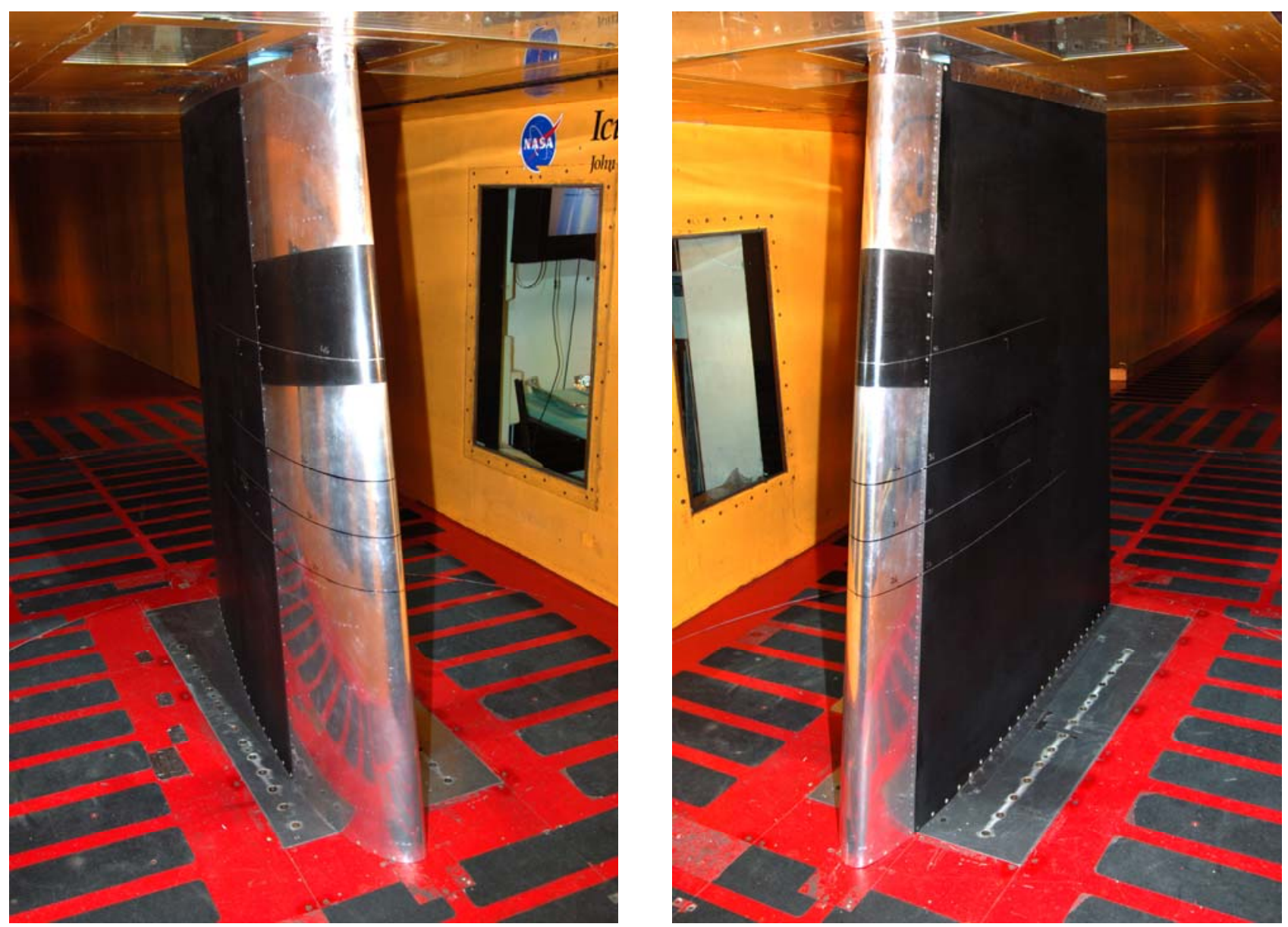

Figure A5. Entry F Business Jet Wing ( $a=$ left) Suction Side, $(b=$ right) Pressure Side. Note: a portion of the aluminum leading edge was painted black for an earlier test. 


\section{Appendix B}

\section{Data Sample}

The images, centerline tracing, mass and ice shape data from the five different models from a high-repeat case are presented here. The case is 7575: $V=$ $200 \mathrm{kts}, T_{-} t=-10{ }^{\circ} \mathrm{C}, \mathrm{LWC}=0.7 \mathrm{~g} / \mathrm{m}^{3}, \mathrm{MVD}=119$ $\mu \mathrm{m}$. Note: all heights are in inches, angles in degrees and mass in grams.

The first time a particular spray condition was run, it was denoted by its 4-digit reference number, e.g., 7575. Subsequent sprays were designated by appending 'r1', 'r2', etc., e.g., 7575r1. For Entries C, D and $E$, a day (nominally 8 sprays) was devoted to running without the heaters. This modified condition was noted by appending an 'm', e.g., 7575m. Mass could not be measured for these runs.

Images in the top row show the close-up shots of the pressure, leading edge and suction sides. The particular suction/pressure side orientation in noted for each model. Images in the second row show the long shots, along with the ice shape tracing data. Note that the 2D tracing data is presented with the suction surface on top, regardless of the model orientation in the tunnel. Finally, a table with the ice shape characteristic data for each repeat is presented, along with their average. For case E-7575, these repeat conditions are coplotted on the 2D tracing data.

The last page contains a runback-type ice shape on the NACA 23012 with and without the heaters, C-1999 and C-1999m: $V=100 \mathrm{kts}, T_{-} t=-5{ }^{\circ} \mathrm{C}, \mathrm{LWC}=1.39 \mathrm{~g} / \mathrm{m}^{3}$, MVD $=225 \mu \mathrm{m}$. For the $\mathrm{C}-1999$ case, the feather region was not captured and/or digitized in detail. After the notch around $x=3.7$ in, which indicates the end of the "solid" ice, only the tops of the feathers were identified. As the accompanying images show, the feathers are aligned with the heater ridges, with bare surface visible in between. This approach was adopted partly due to the questionable value of recording this artificially-aligned aft feather data, and partly due to the extremely labor-intensive process to digitize and append each individual feather. The comparison with the C-1999m tracing, which was faithfully traced, shows the randomly-spaced feathers were roughly the same height as those on the heater. 


\section{B-7575: NLF 0414}
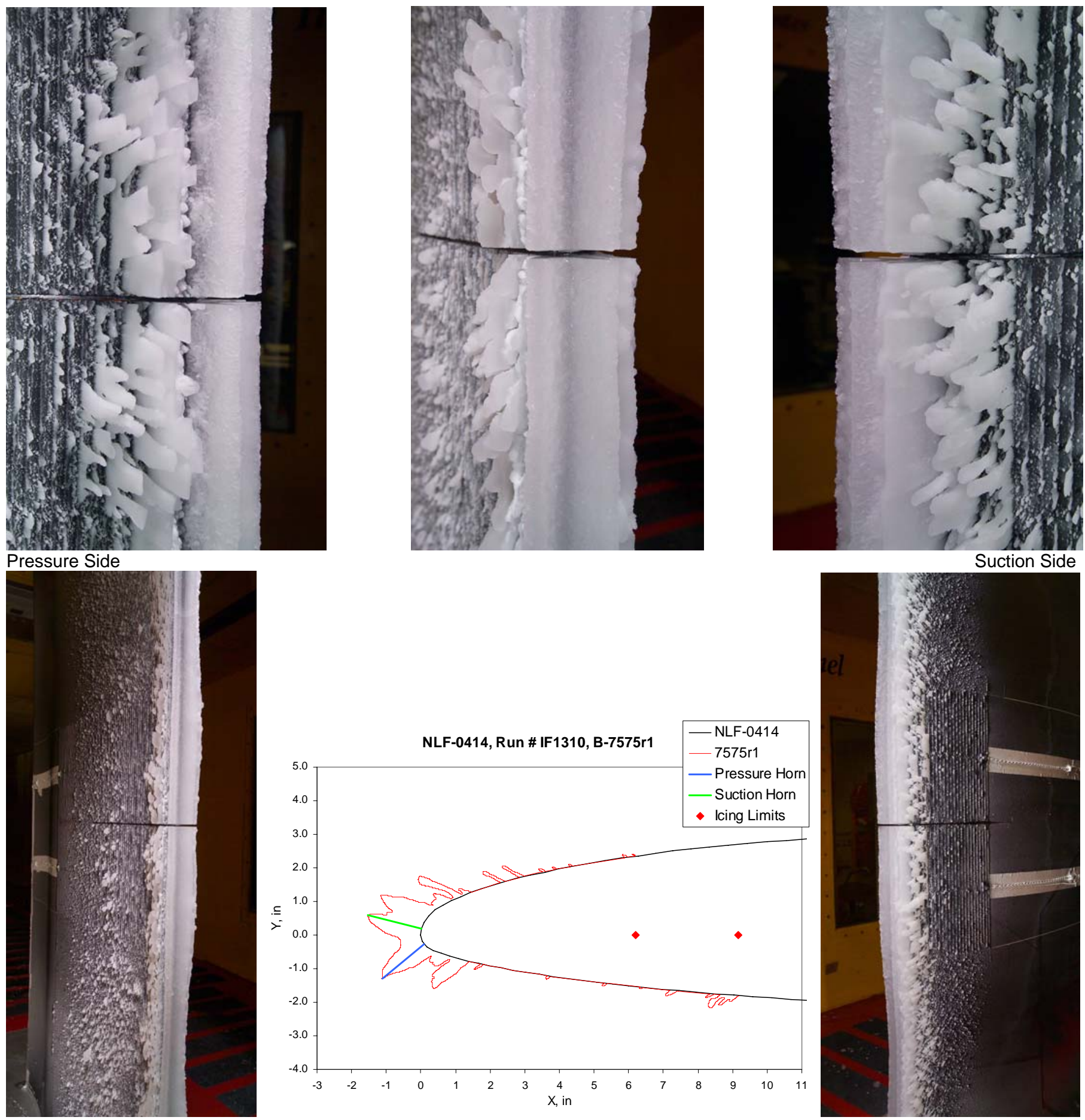

Figure B1. Case B-7575r1 ice accretion ( $\mathrm{a}=$ top left) pressure side, $(\mathrm{b}=$ top center) leading edge, $(\mathrm{c}=$ top right) suction side, $(d=$ bottom left) pressure long shot, $(e=$ bottom center) tracing, $(f=$ bottom right $)$ suction long shot.

Table B1. Ice mass and shape characteristic data for the B-7575 repeat series.

\begin{tabular}{|c|c|c|c|c|c|c|c|c|}
\hline \multicolumn{9}{|c|}{ NLF 0414, $V=200 \mathrm{kts}, T_{-} t=-10^{\circ} \mathrm{C}, \mathrm{AOA}=2^{\circ}$} \\
\hline Ref & LWC & MVD & \multicolumn{2}{|c|}{ Pressure Side Horn } & \multicolumn{2}{|c|}{ Suction Side Horn } & Mass & LE Min \\
\hline & & & Thickness & Angle & Thickness & Angle & & \\
\hline B-7575r1 & 0.7 & 119 & 1.59 & 228.82 & 1.60 & 158.84 & 1123 & 0.600 \\
\hline B-7575r2 & 0.7 & 119 & 1.58 & 227.51 & 1.59 & 159.87 & 1129 & 0.621 \\
\hline B-avg & 0.7 & 119 & 1.585 & 228.16 & 1.595 & 159.355 & 1126 & 0.611 \\
\hline
\end{tabular}

Note: B-7575 did not spray properly, and therefore is excluded from analyses. 
C-7575: NACA 23012

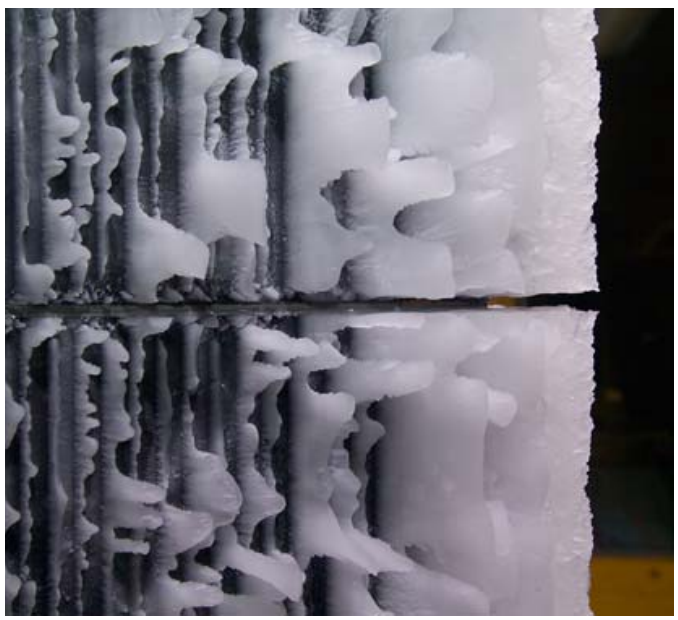

Pressure Side

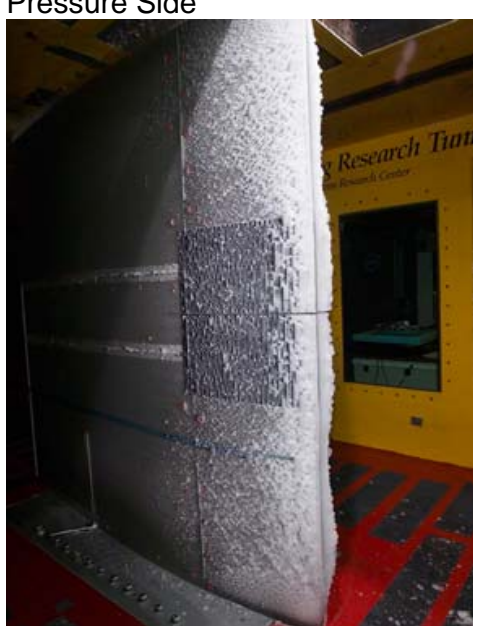

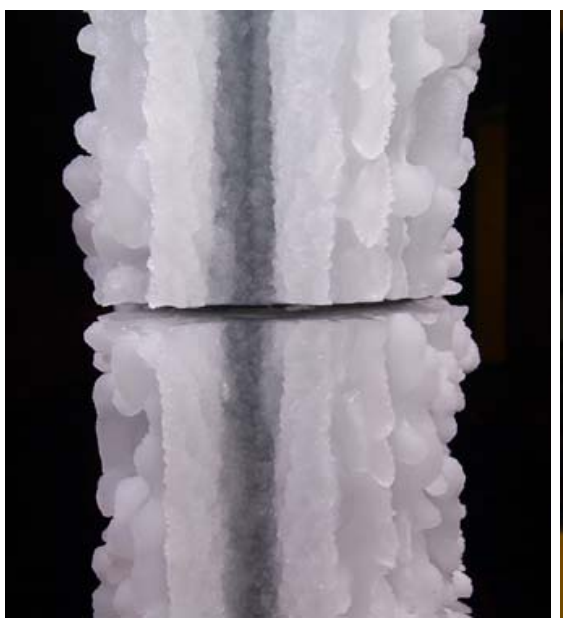

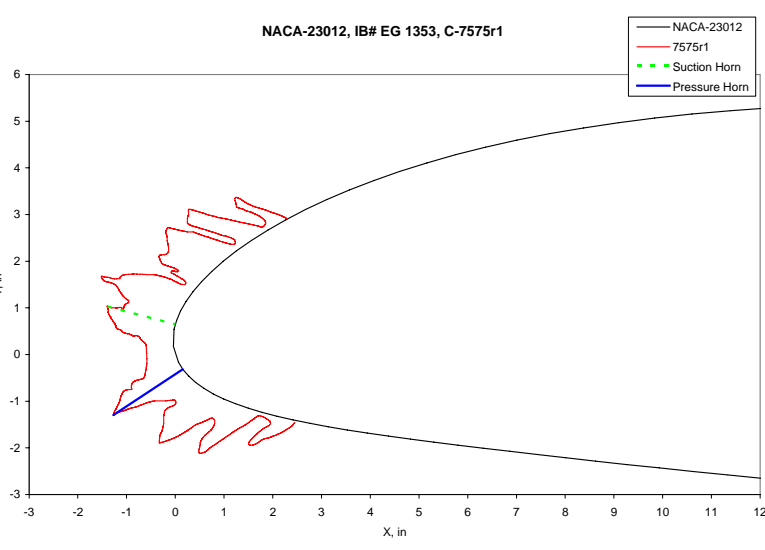

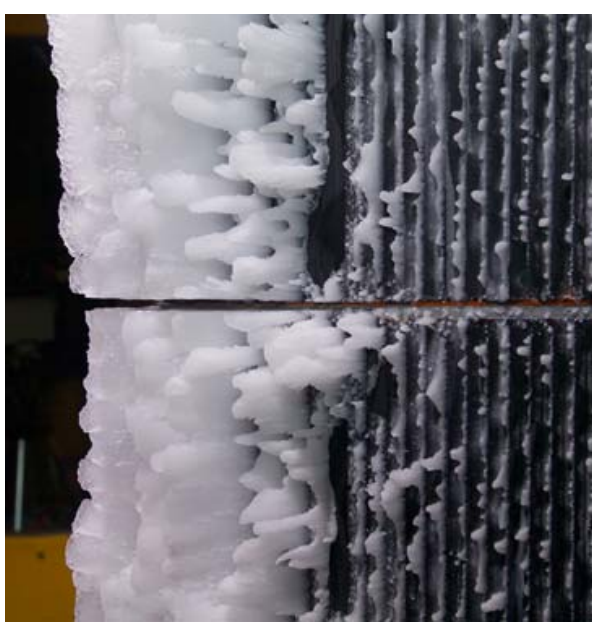

Suction Side

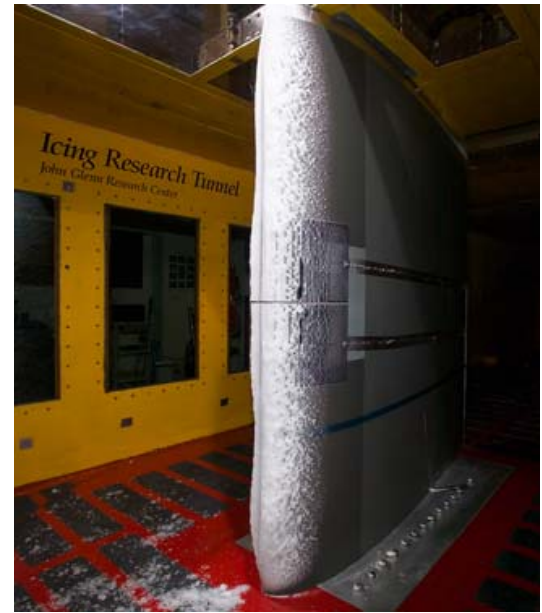

Figure B2. Case C-7575r1 ice accretion ( $\mathrm{a}=$ top left) pressure side, $(\mathrm{b}=$ top center) leading edge, $(\mathrm{c}=$ top right) suction side, $(d=$ bottom left) pressure long shot, $(e=$ bottom center $)$ tracing, $(f=$ bottom right $)$ suction long shot.

Table B2. Ice mass and shape characteristic data for the C-7575 repeat series.

\begin{tabular}{|c|c|c|c|c|c|c|c|c|}
\hline \multicolumn{9}{|c|}{ NACA $23012, V=200 \mathrm{kts}, T_{-} t=-10^{\circ} \mathrm{C}, \mathrm{AOA}=2^{\circ}$} \\
\hline \multirow[t]{2}{*}{ Ref } & \multirow[t]{2}{*}{ LWC } & \multirow[t]{2}{*}{ MVD } & \multicolumn{2}{|c|}{ Pressure Side Horn } & \multicolumn{2}{|c|}{ Suction Side Horn } & \multirow[t]{2}{*}{ Mass } & \multirow[t]{2}{*}{ LE Min } \\
\hline & & & Thickness & Angle & Thickness & Angle & & \\
\hline C-7575 & 0.7 & 119 & 1.519 & 228.9 & 1.36 & 148.9 & 1850 & 0.587 \\
\hline C-7575r1 & 0.7 & 119 & 1.731 & 230.0 & 1.44 & 147.7 & 1867 & 0.554 \\
\hline C-7575r2 & 0.7 & 119 & 1.525 & 230.8 & 1.31 & 145.7 & 1886 & 0.548 \\
\hline C-7575m & 0.7 & 119 & 1.483 & 232.8 & 1.28 & 146.3 & - & 0.564 \\
\hline C-avg & 0.7 & 119 & 1.565 & 230.6 & 1.35 & 147.1 & 1868 & 0.563 \\
\hline
\end{tabular}




\section{D-7575: GLC 305}
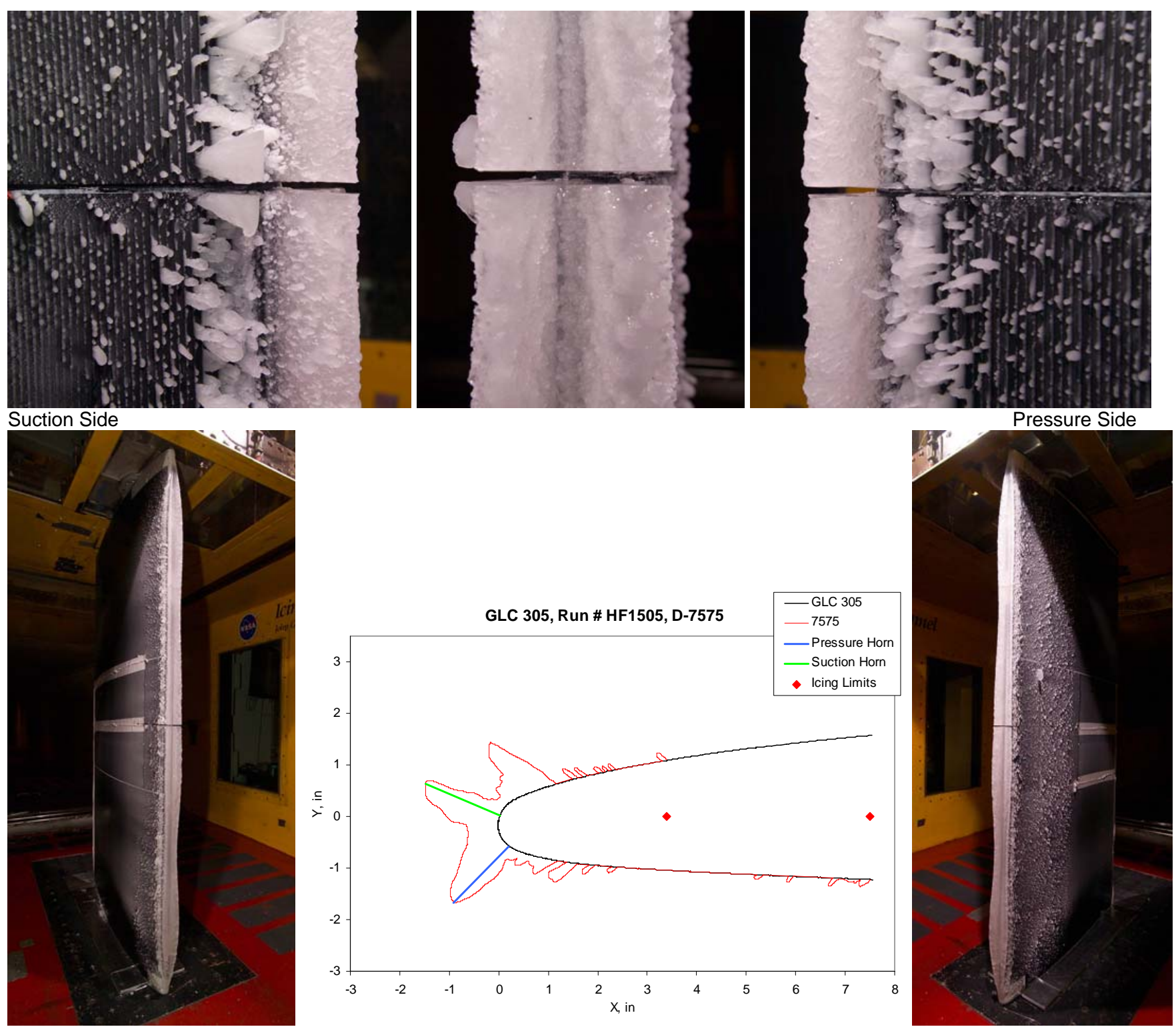

Figure B3. Case D-7575 ice accretion ( $\mathrm{a}=$ top left $)$ suction side, $(\mathrm{b}=$ top center) leading edge, $(\mathrm{c}=$ top right) pressure side, $(d=$ bottom left) suction long shot, $(e=$ bottom center) tracing, $(f=$ bottom right) pressure long shot.

Table B3. Ice mass and shape characteristic data for the D-7575 repeat series.

\begin{tabular}{|l|r|r|r|r|r|r|r|r|}
\hline \multicolumn{1}{|c|}{ Ref } & LWC & MVD & \multicolumn{2}{|c|}{ Pressure Side Horn } & \multicolumn{2}{|c|}{ Suction Side Horn } & Mass & LE Min \\
\hline & & & Thickness & Angle & Thickness & Angle & & \\
\hline D-7575 & 0.7 & 119 & 1.549 & 238.6 & 1.617 & 150.4 & 675 & 0.616 \\
\hline D-7575r2 & 0.7 & 119 & 1.477 & 231.2 & 1.535 & 157.8 & 730 & 0.673 \\
\hline D-7575m & 0.7 & 119 & 1.868 & 224.4 & 1.930 & 160.4 & - & 0.675 \\
\hline D-avg & 0.7 & 119 & 1.631 & 231.4 & 1.694 & 156.2 & 702.5 & 0.655 \\
\hline
\end{tabular}




\section{E-7575: COMMERCIAL TAIL}
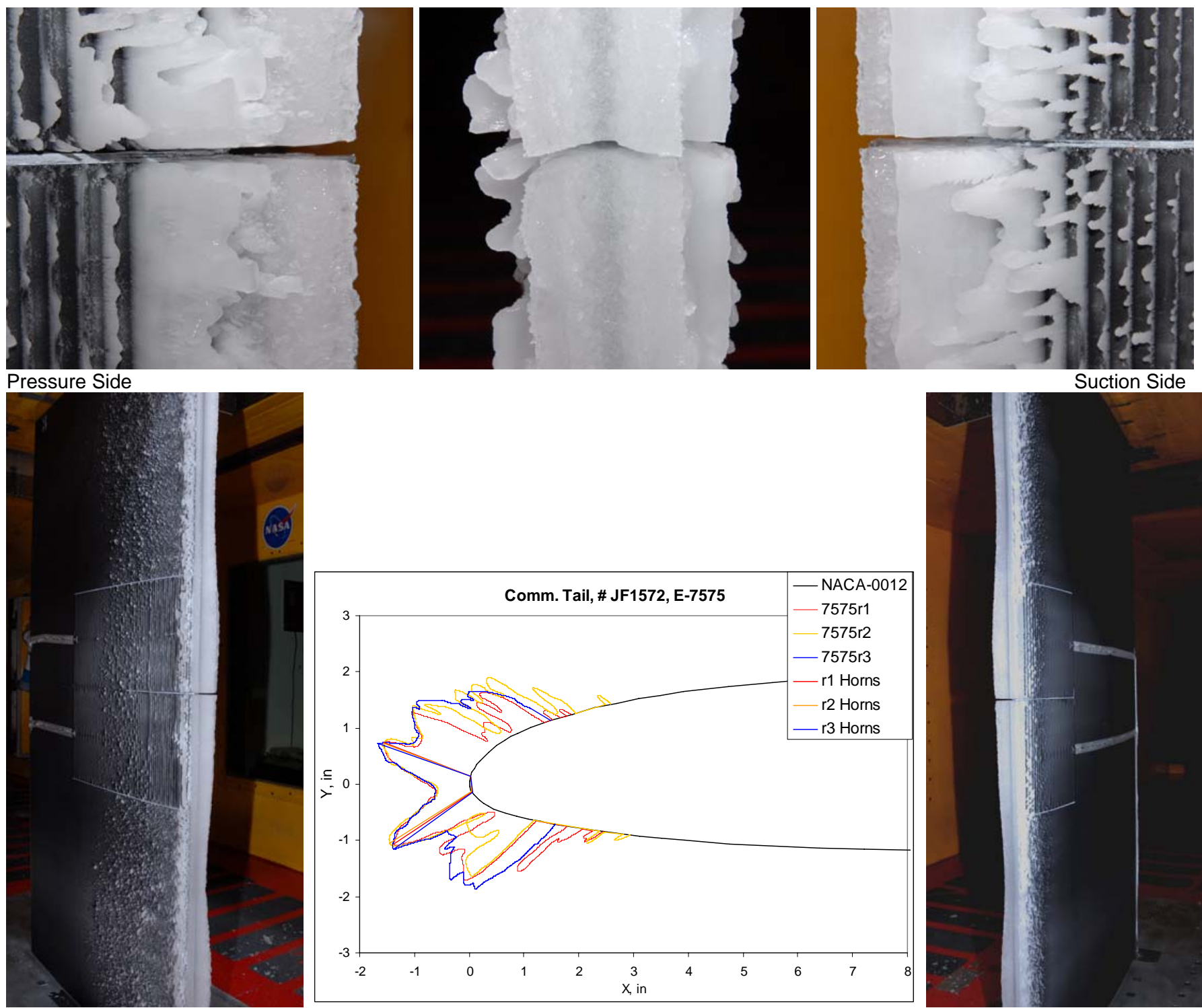

Figure B4. Case E-7575r1 ice accretion ( $a=$ top left) pressure side, $(b=$ top center) leading edge, $(c=$ top right) suction side, $(d=$ bottom left $)$ pressure long shot, $(e=$ bottom center $)$ multiple tracings, $(f=$ bottom right $)$ suction long shot.

Table B4. Ice mass and shape characteristic data for the E-7575 repeat series.

\begin{tabular}{|l|r|r|r|r|r|r|r|r|}
\hline \multicolumn{1}{|c|}{ Ref } & LWC & MVD & \multicolumn{2}{|c|}{ Pressure Side Horn } & \multicolumn{2}{c|}{ Suction Side Horn } & \multicolumn{1}{c|}{ Mass } & LE Min \\
\hline & & & Thickness & Angle & Thickness & Angle & & \\
\hline E-7575* & 0.7 & 119 & 1.712 & 218.1 & 1.630 & 155.2 & $947^{*}$ & 0.587 \\
\hline E-7575r1 & 0.7 & 119 & 1.706 & 219.0 & 1.691 & 156.1 & 970 & 0.611 \\
\hline E-7575r2 & 0.7 & 119 & 1.757 & 217.3 & 1.692 & 156.9 & 977 & 0.580 \\
\hline E-7575r3 & 0.7 & 119 & 1.757 & 221.1 & 1.788 & 157.8 & 975 & 0.624 \\
\hline E-avg & 0.7 & 119 & 1.733 & 218.9 & 1.700 & 156.5 & 974 & 0.600 \\
\hline
\end{tabular}

*This was the first run of the night. Mass is expected to be up to 10 percent low, and is not included in the average. 


\section{F-7575: BUSINESS JET WING}
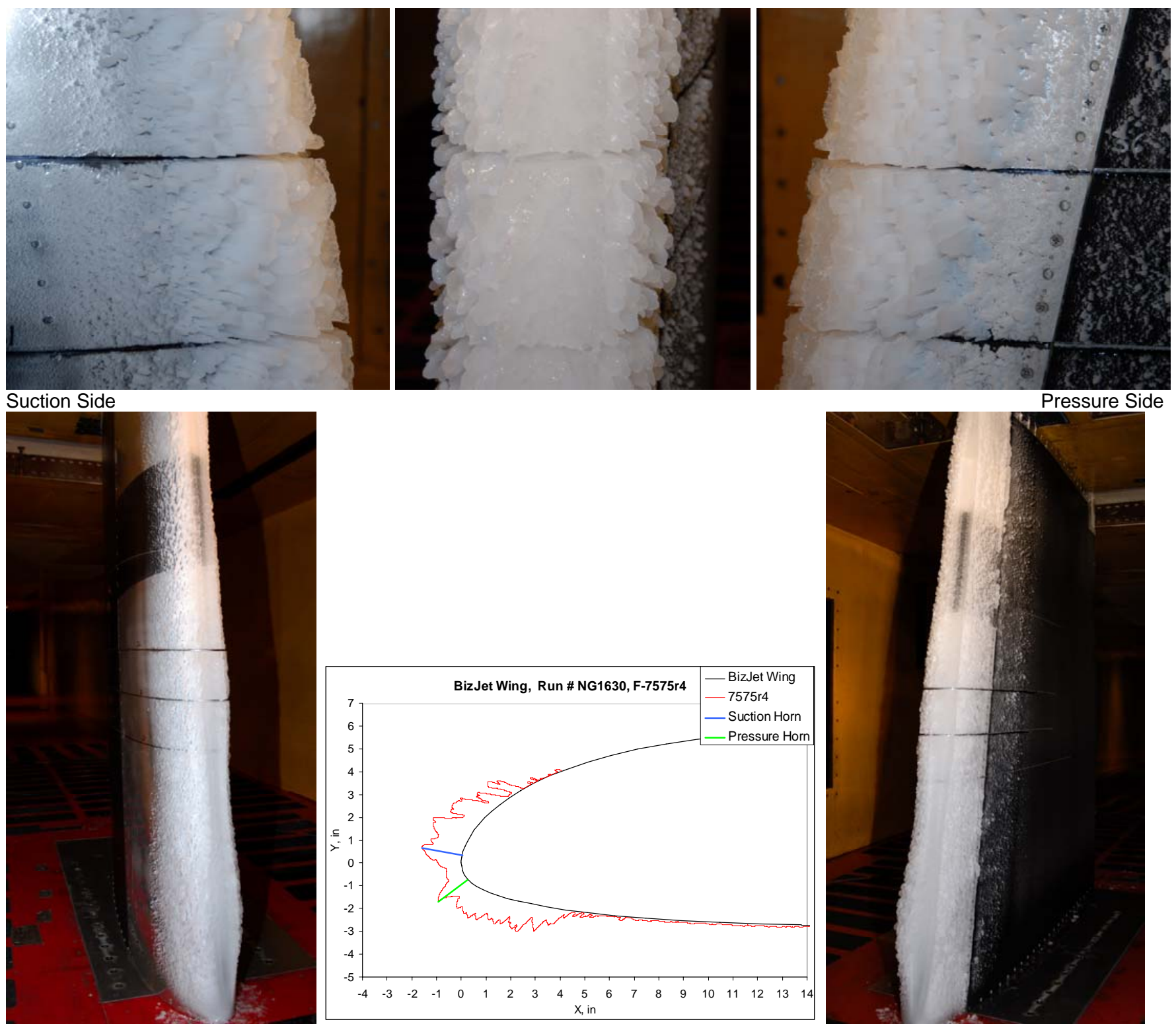

Figure B5. Case F-7575r4 ice accretion ( $a=$ top left) suction side, $(b=$ top center) leading edge, $(c=$ top right $)$ pressure side, $(d=$ bottom left) suction long shot, $(e=$ bottom center) tracing, $(f=$ bottom right $)$ pressure long shot.

Table B5. Ice mass and shape characteristic data for the F-7575 repeat series.

\begin{tabular}{|l|r|r|r|r|r|r|r|r|}
\hline \multicolumn{1}{|c|}{ Ref } & LWC & MVD & \multicolumn{2}{c|}{ Pressure Side Horn } & \multicolumn{2}{c|}{ Suction Side Horn } & \multicolumn{1}{c|}{ Mass } & \multicolumn{1}{c|}{ LE Min } \\
\hline & & & Thickness & Angle & Thickness & Angle & & \\
\hline F-7575 & 0.7 & 119 & 1.513 & 241.2 & 1.400 & 132.9 & 1921 & 0.572 \\
\hline F-7575r1* & 0.7 & 119 & 1.446 & 236.2 & 1.509 & 152.6 & $1872^{*}$ & 0.604 \\
\hline F-7575r2 & 0.7 & 119 & 1.364 & 243.1 & 1.541 & 140.0 & 1913 & 0.596 \\
\hline F-7575r3* & 0.7 & 119 & 1.575 & 235.7 & 1.752 & 152.1 & - & 0.664 \\
\hline F-7575r4 & 0.7 & 119 & 1.511 & 240.5 & 1.671 & 156.1 & - & 0.614 \\
\hline F-avg & 0.7 & 119 & 1.482 & 239.3 & 1.575 & 146.7 & 1917 & 0.610 \\
\hline
\end{tabular}

*These were the first runs of the night. Mass is expected to be up to 10 percent low, and is not included in the average. 
C-1999: NACA $23012\left(V=100 \mathrm{KTS}, T_{-}\right.$TOT $\left.=-5^{\circ} \mathrm{C}, \mathrm{LWC}=1.39 \mathrm{G}^{\mathrm{M}} \mathrm{M}^{3}, \mathrm{MVD}=225 \mu \mathrm{M}\right)$

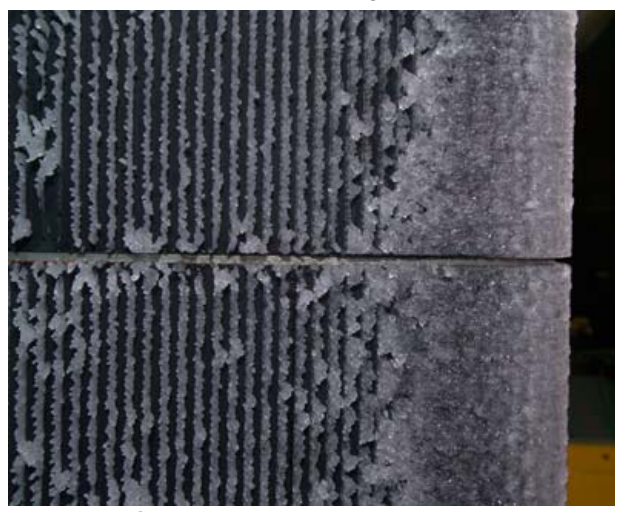

Pressure Side
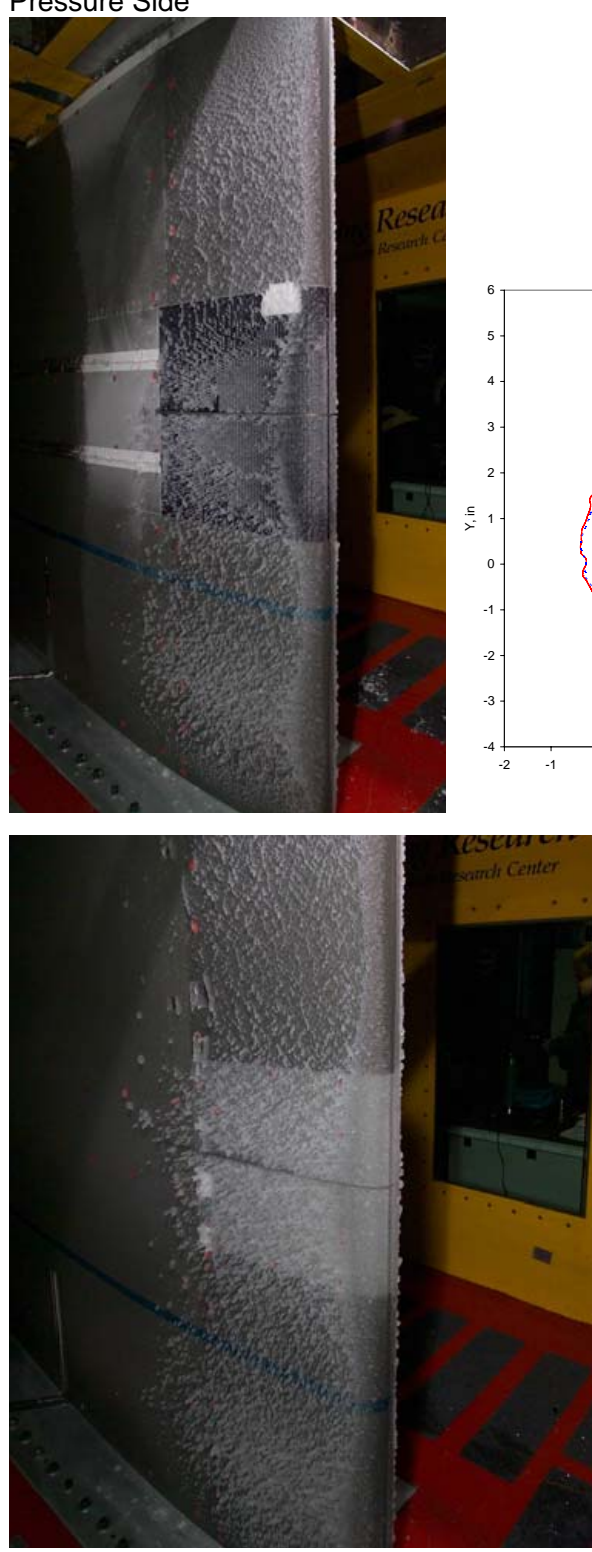
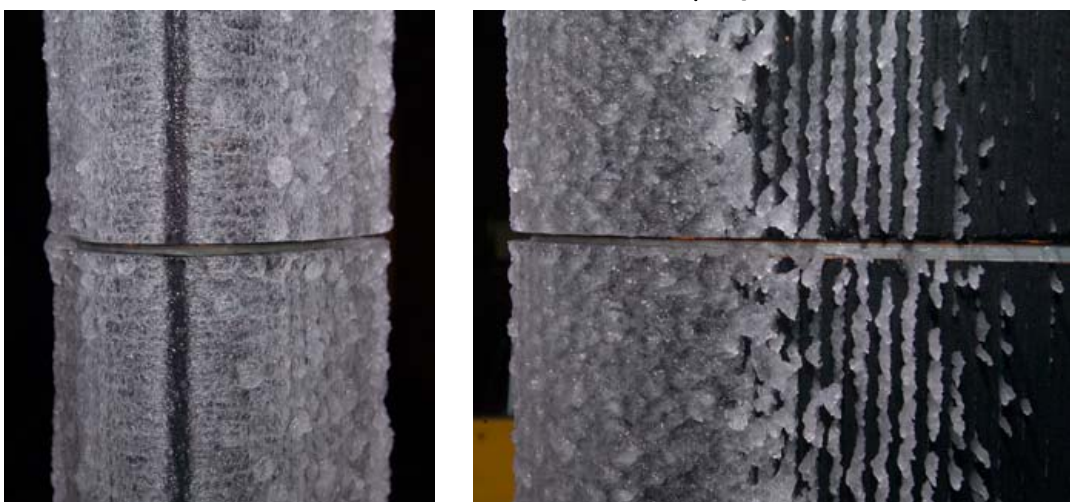

Suction Side

NACA 23012, C- 1999 \& C-1999m
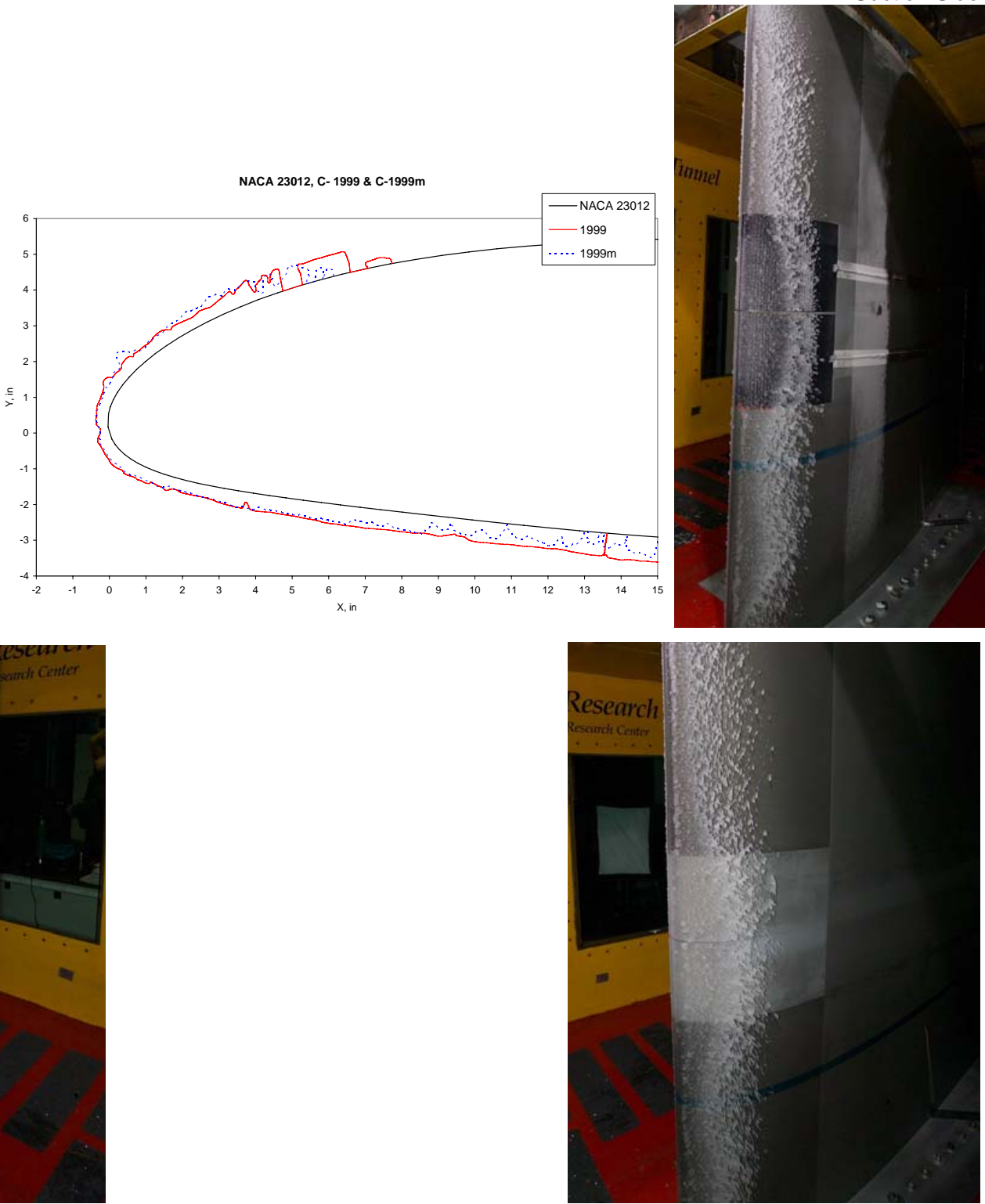

Figure B6. Case C-1999 ice accretion ( $\mathrm{a}=$ top left) pressure side, $(\mathrm{b}=$ top center) leading edge, $(\mathrm{c}=$ top right) suction side, $(\mathrm{d}=$ middle left) pressure long shot, $(\mathrm{e}=$ middle center) tracing of $\mathrm{C}-1999$ and $\mathrm{C}-1999 \mathrm{~m},(\mathrm{f}=$ middle right) pressure long shot. ( $g$ = bottom left) Case C-1999m pressure long shot, $(\mathrm{h}=$ bottom right) $\mathrm{C}-1999 \mathrm{~m}$ suction long shot. 


\section{References}

1. National Transportation Safety Board website, http://www.ntsb.gov/Recs/mostwanted/aviation_issu es.htm, accessed Apr 2007.

2. Miller, Dean R., Potapczuk, Mark G. and Bond, Thomas H., Update of SLD Engineering Tools Development, SAE 2003-01-2127, Jun 2003.

3. Miller, Dean R., Potapczuk, Mark G and Langhals, Tammy J., Additional Investigations of Ice Shape Sensitivity to Parameter Variations, NASA/TM2006-214227, AIAA-2006-0469, Mar 2006.

4. Addy, Harold E., Ice Tracing Guidelines, NASA Glenn Research Center-Icing Branch internal document, Mar 2006.
5. Ide, Robert F., email correspondence: SLD Cloud Accuracy Question, 15 May 2007.

6. Potapczuk, Mark G. and Miller, Dean, Numerical Simulation of Ice Shapes from a Bimodal Large Droplet Icing Cloud, AIAA-2006-0462, Jan 2006.

7. Addy, Harold E, Ice Accretions and Icing Effects for Modern Airfoils, NASA/TP-2000-210031 and DOT/FAA/AR-99/89, Apr 2000.

8. Van Zante, Judith F., SLD Ice Shape Database, to be published as a NASA CR, target date: Mar 2008.

9. Van Zante, Judith F. and Ferraro, Matthew R., SLD Ice Shape Database, DVD, Aug 2007.

10. Wright, William J., LEWICE 3.0 Users Manual, May 2004. 


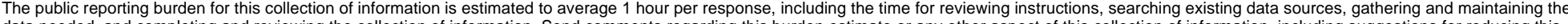

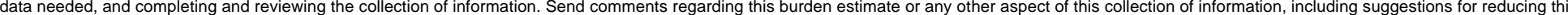

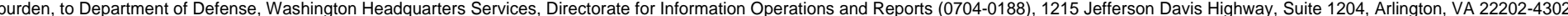

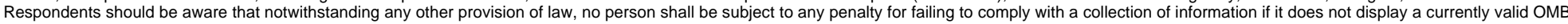
control number.

PLEASE DO NOT RETURN YOUR FORM TO THE ABOVE ADDRESS.

\begin{tabular}{|l|l}
\hline $\begin{array}{l}\text { 1. REPORT DATE }(D D-M M-Y Y Y Y) \\
01-09-2007\end{array}$ & $\begin{array}{l}\text { 2. REPORT TYPE } \\
\text { Final Contractor Report }\end{array}$ \\
\hline
\end{tabular}

\section{TITLE AND SUBTITLE}

A Database of Supercooled Large Droplet Ice Accretions

\section{DATES COVERED (From - To)}

\section{5a. CONTRACT NUMBER}

NNC06BA07B

5b. GRANT NUMBER

5c. PROGRAM ELEMENT NUMBER

5d. PROJECT NUMBER

6. AUTHOR(S)

Van Zante, Judith, Foss

5e. TASK NUMBER

5f. WORK UNIT NUMBER

WBS 122711.03.11.03.04.04.01

\section{PERFORMING ORGANIZATION NAME(S) AND ADDRESS(ES)}

ASRC Aerospace Corporation

\section{PERFORMING ORGANIZATION REPORT NUMBER}

Cleveland, Ohio 44135

E-16222

\section{SPONSORING/MONITORING AGENCY NAME(S) AND ADDRESS(ES)}

National Aeronautics and Space Administration

Washington, DC 20546-0001

\section{SPONSORING/MONITORS ACRONYM(S) \\ NASA}

\section{SPONSORING/MONITORING} REPORT NUMBER

NASA/CR-2007-215020; 2007-01-3348

\section{DISTRIBUTIONIAVAILABILITY STATEMENT}

Unclassified-Unlimited

Subject Categories: 02, 03, and 09

Available electronically at http://gltrs.grc.nasa.gov

This publication is available from the NASA Center for AeroSpace Information, 301-621-0390

\section{SUPPLEMENTARY NOTES}

This document contains a DVD, NASA/CR-2007-215020/SUPPL, which contains the SLD Icing Database and PDF of this report.

\section{ABSTRACT}

A unique, publicly available database regarding supercooled large droplet ice accretions has been devel-oped in NASA Glenn’s Icing Research Tunnel. Identical cloud and flight conditions were generated for five different airfoil models. The models chosen represent a variety of aircraft types from the horizontal stabilizer of a large trans-port aircraft to the wings of regional, business, and general aviation aircraft. In addition to the standard documentation methods of 2D ice shape tracing and imagery, ice mass measurements were also taken. This database will also be used to validate and verify the extension of the ice accretion code, LEWICE, into the SLD realm.

\section{SUBJECT TERMS}

Supercooled large droplet; Icing; Ice; Database; Ice formation

\begin{tabular}{|c|c|c|c|}
\hline 16. SECURI' & ASSIFICATION & & 17. LIMITATION OF \\
\hline $\begin{array}{l}\text { a. REPORT } \\
U\end{array}$ & $\begin{array}{l}\text { b. ABSTRACT } \\
U\end{array}$ & $\begin{array}{l}\text { c. THIS } \\
\text { PAGE } \\
\text { U }\end{array}$ & UU \\
\hline
\end{tabular}

18. NUMBER
OF
PAGES
24

19a. NAME OF RESPONSIBLE PERSON
STI Help Desk (email:help@sti.nasa.gov)
19b. TELEPHONE NUMBER (include area code)
301-621-0390

Standard Form 298 (Rev. 8-98) Prescribed by ANSI Std. Z39-18 

